\title{
Hypercoordinate Aryltrialkylsilanes and -stannanes and Their Use in the Synthesis of Homodinuclear Organometallic Complexes with a 1,4-Phenylene Bridge ${ }^{\dagger}$
}

\author{
Pablo Steenwinkel,, J ohann T. B. H. J astrzebski, ${ }^{\ddagger}$ Berth-J an Deelman,,,$\S$ \\ David M. Grove, ‡ Huub Kooijman," Nora Veldman," Wilberth J . J . Smeets," \\ Anthony L. Spek,,$" \perp$ and Gerard van Koten*,‡ \\ Debye Institute, Department of Metal-Mediated Synthesis, Utrecht University, \\ Padualaan 8, $3584 \mathrm{CH}$ Utrecht, The Netherlands, EIf Atochem VIissingen BV, P.O. Box 70, \\ 4380 AB Vlissingen, The Netherlands, and Bijvoet Center for Biomolecular Research, \\ Department of Crystal and Structural Chemistry, Utrecht University, Padualaan 8, \\ $3584 \mathrm{CH}$ Utrecht, The Netherlands
}

Received J une 10, $1997^{\otimes}$

\begin{abstract}
New mono- and dinuclear aryltrialkylsilanes and -stannanes $\left[\mathrm{Me}_{3} \mathrm{M}\left\{\mathrm{C}_{6} \mathrm{H}_{3}\left(\mathrm{CH}_{2} \mathrm{NMe}_{2}\right)_{2}\right.\right.$ 2,6\}] $(\mathrm{M}=\mathrm{Si}(5), \mathrm{Sn}(6))$ and [( $\left.\left.\mathrm{Me}_{3} \mathrm{M}\right)_{2}-1,4-\left\{\mathrm{C}_{6}\left(\mathrm{CH}_{2} \mathrm{NMe}_{2}\right)_{4}-2,3,5,6\right\}\right](\mathrm{M}=\mathrm{Si}(\mathbf{9})$, Sn (10)) have been prepared from transmetalation reactions of dimeric $\left[\mathrm{Li}\left\{\mathrm{C}_{6} \mathrm{H}_{3}\left(\mathrm{CH}_{2} \mathrm{NMe}_{2}\right)_{2}-2,6\right\}\right]_{2}$ and new polymeric $\left[\mathrm{Li}_{2}-1,4-\left\{\mathrm{C}_{6}\left(\mathrm{CH}_{2} \mathrm{NMe}_{2}\right)_{4}-2,3,5,6\right\}\right]_{\infty}$ with (trimethylsilyl)trifluoromethanesulfonate or trimethyltin chloride. The X-ray crystal structures of dinuclear $\mathbf{9}$ and $\mathbf{1 0}$ have been determined and in the molecular geometries found the central 1,4-phenylene dimetalated aryl ligand system provides bidentate $\mathrm{C}, \mathrm{N}$-coordination to silicon in $\mathbf{9}$ and terdentate pseudofacial $\mathrm{N}, \mathrm{C}, \mathrm{N}^{\prime}$-coordination to tin in 10. Reactions of the newly prepared silanes $\mathbf{5}$ and 9 and stannanes $\mathbf{6}$ and $\mathbf{1 0}$ with diverse palladium(II) and platinum(II) substrates afford organometallic products arising from both aryl and methyl group transfer. For example, the reaction of dinudlear stannane $\mathbf{1 0}$ (or dinuclear silane 9) with palladium(II) species gives the bimetallic complex $\left[(\mathrm{PdCl})_{2}-1,4-\left\{\mathrm{C}_{6}\left(\mathrm{CH}_{2} \mathrm{NMe}_{2}\right)_{4}-2,3,5,6\right\}\right]$ (15), wher eas its reaction with $\left[\mathrm{PtCl}_{2}(\mathrm{COD})\right]\left(\mathrm{COD}=\right.$ cycloocta-1,5-diene) or $\mathrm{Me}_{3} \mathrm{SnCl}$ gives the ionic tin(IV) species [( $\mathrm{Me}_{2}-$ $\left.\mathrm{Sn})_{2}-1,4-\left\{\mathrm{C}_{6}\left(\mathrm{CH}_{2} \mathrm{NMe}_{2}\right)_{4}-2,3,5,6\right\}\right]^{2+}\left(\mathrm{X}^{-}\right)_{2}$ with $\mathrm{X}$ being $\mathrm{Cl}(\mathbf{1 8 a})$ or $\mathrm{Me}_{3} \mathrm{SnCl}_{2}$ (18b). The X-ray crystal structure of $\mathbf{1 8 b}$ has been determined and the molecular geometry found shows that the central dimetalated aryl ligand system provides terdentate meridional N,C,N'-coordination to both tin centers.
\end{abstract}

\section{Introduction}

Organometallic complexes of the group 14 (IVB) metals silicon and tin remain a topic of interest because the formally tetracoordinate species as a class usually have weak Lewis acidic properties, and this provides a potential means of influencing their reactivity when they are used as alkylating or arylating reagents. For example, tetracoordinate mixed aryl/alkylstannanes can selectively transfer their aryl group to a transition metal center, a process that has been used extensively in the Stille reaction. ${ }^{1}$ This process involves a transfer of an organyl ligand (usually the aryl group in mixed aryl/ alkylstannanes) from tin to palladium. The same process of aryl transfer from a stannane has also been

* To whom correspondence should be addressed: tel, +31 30253 3120; fax, +31 30252 3615; e-mail, vankoten@xray.chem.ruu.nl.

† We propose to use the term "hypercoordinate" instead of "hypervalent". For example, in the tetraorganotin compounds described in this paper, it is not the formal oxidation state of the tin cation that changes but actually it is its ligand environment, which is extended from the anticipated four to five, six, or seven neutral or anionic donor sites. The ligands each contribute one or a multiple number of electron pairs for binding. Using bidentate monoanionic $\mathrm{C}, \mathrm{N}$-coordinating ligands the primary $\mathrm{Sn}-\mathrm{C}$ interaction is complemented by $\mathrm{Sn}-\mathrm{N}$ binding promoted by entropy effects. In a separate paper we will address this point in more detail.

$¥$ Debye Institute, Utrecht University.

$\S$ Elf Atochem Vlissingen BV.

Bijvoet Center for Biomolecular Research, Utrecht University.

${ }^{\perp}$ Address correspondence pertaining to crystallographic studies to this author; e-mail, spea@xray.chem.ruu.nl.

${ }^{\otimes}$ Abstract published in AdvanceACS Abstracts, November 1, 1997. used for the selective synthesis of monoaryl transition metal complexes ${ }^{2}$ since aryl transfer from aryllithium, arylzinc, or Grignard reagents often results in mixtures of mono- and diarylated transition metal species. However, intramolecularly coordinated organometallic tin(IV) compounds have, compared to their tetracoordinate analogs, 3,4 different reactivity patterns and different spectroscopic properties. This subject has been reviewed by J astrzebski and van Koten. ${ }^{4 c}$

Similarly, the reactivity and (spectroscopic) properties of silicon(IV) compounds with an expanded silicon coordination sphere differ substantially from the tetracoordinate silanes, ${ }^{5}$ and Chuit et al. ${ }^{5 a}$ have reviewed silanes in which intramolecular oxygen and nitrogen

(1) (a) Kosugi, M.; Sasazawa, K.; Shimizu, Y.; Migita, T. Chem. Lett 1977, 301. (b) Kosugi, M.; Migita, T. Yuki Gose Kagaku Kyokaishi 1980, 38, 1142. (c) Bailey, T. R. Tetrahedron Lett. 1986, 27, 4407. (d) Sheffy, F. K.; Godschalx, J . P.; Stille, J. K. J . Am. Chem. Soc. 1984 106, 4833. (e) Labadie, J. W.; Stille, J. K. J. Am. Chem. Soc. 1983, 105, 6129. (f) Brown, J . M.; Pearson, M.; J astrzebski, J . T. B. H.; van Koten, G. J . Chem. Soc., Chem. Commun. 1992, 1440.

(2) Brune, H. A.; Müller, W.-D. Chem. Ber. 1986, 119, 759.

(3) (a) van Koten, G.; J astrzebski, J. T. B. H.; Noltes, J. G.; Verhoeckx, G. J .; Spek, A. L.; Kroon, J . J . Chem. Soc., Dalton Trans. 1980, 1352. (b) J urkschat, K.; Tzschach, A.; Meunier-Piret, J.J . Organomet. Chem. 1985, 290, 285. (c) Kumar Das, V. G.; Mun, L. K.; Wei, C.; Mak, T. C. W. Organometallics 1987, 6, 10.

(4) (a) J astrzebski, J. T. B. H.; Knaap, C. T.; van Koten, G. J . Organomet. Chem. 1983, 255, 287. (b) J astrzebski, J . T. B. H.; Boersma, J.; Esch, P. M.; van Koten, G. Organometallics 1991, 10, 930. (c) J astrzebski, J . T. B. H.; van Koten, G. Adv. Organomet. Chem. 1993, 35, 241. (d) van Koten, G.; Noltes, J . G. J . Am. Chem. Soc. 1976, 98, 5393. 


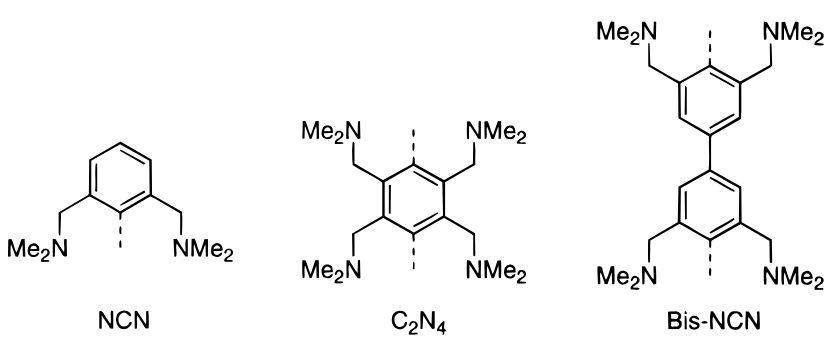

Figure 1. Schematic representation of the mono- and dianionic potentially (bis-) N,C,N'-terdentate coordinating aminoaryl ligands $\mathrm{NCN}, \mathrm{C}_{2} \mathrm{~N}_{4}$, and bis-NCN.

coordination provide penta-, hexa-, and even heptacoordinate silicon nuclei.

In our group, we have for many years employed aryl ligands with potentially coordinating $\mathrm{N}$-donor substituents for the preparation and study of unusual organometallic species, ${ }^{6}$ some of which have been shown to have application in metal-mediated and metal-catalyzed reactions. ${ }^{7}$ The most commonly used ligand of this type has been the monoanionic aryldiamine ligand $\left[\mathrm{C}_{6} \mathrm{H}_{3}\left(\mathrm{CH}_{2}-\right.\right.$ $\left.\left.\mathrm{NMe}_{2}\right)_{2}-2,6\right]^{-}(\mathrm{NCN})$, shown in Figure 1, which often functions as a terdentate $\mathrm{N}, \mathrm{C}, \mathrm{N}^{\prime}$-coordinating ligand. More recently, we have also employed dianionic arylamine ligands such as $\left[\mathrm{C}_{6}\left(\mathrm{CH}_{2} \mathrm{NMe}_{2}\right)_{4}-2,3,5,6\right]^{2-}\left(\mathrm{C}_{2} \mathrm{~N}_{4}\right)$ and $\left[4,4^{\prime}-\left\{\mathrm{C}_{6} \mathrm{H}_{2}\left(\mathrm{CH}_{2} \mathrm{NMe}_{2}\right)_{2}-2,6\right\}_{2}\right]^{2-}$ (bis-NCN; see Figure 1), for the preparation of dinuclear mono- and biphenylene-bridged organometallic complexes. ${ }^{8}$ Such species may have potential in the field of bimetallic catalysis and in the development of organometallic polymers ${ }^{9}$ and of molecules with interesting (el ectronic) properties.

As a complementary aspect of these recent studies, we are interested in preparing mixed aryl/alkylsilane and -stannane complexes based on such arylamine ligands as novel alkylating or arylating reagents for the preparation of multimetallic systems. The present report concentrates on the preparation and characterization of new mono- and dinuclear silicon(IV) and tin(IV) complexes of $\mathrm{NCN}$ and $\mathrm{C}_{2} \mathrm{~N}_{4}$ in which $\mathrm{N}$-donor coordination to the metal centers has been established. The application of the silane and stannane complexes of $\mathrm{C}_{2} \mathrm{~N}_{4}$ as reagents for a potential entry into new bimetallic complexes of platinum and palladium is

(5) (a) Chuit, C.; Corriu, R. J . P.; Reyé, C.; Young, J . C. Chem. Rev. 1993, 93, 1371. (b) Carré, F.; Chuit, C.; Corriu, R. J. P.; Mehdi, A.; Reyé, C. Angew. Chem., Int. Ed. Engl. 1994, 33, 1097. (c) Auner, N. Probst, R.; Herdtweck, E. J . Organomet. Chem. 1993, 459, 25. (d) Brelière, C.; Carré, F.; Corriu, R. J. P.; Royo, G.; Wong Chi Man, M.; Lapasset, J . Organometallics 1994, 13, 307.

(6) (a) van Koten, G. PureAppl. Chem. 1989, 61, 1681 and references therein. (b) Rietveld, M. H. P.; Grove, D. M.; van Koten, G. New J . Chem. 1997, 21, 751.

(7) (a) Knapen, J . W. J .; van der Made, A. W.; de Wilde, J . C.; van Leeuwen, P. W. N. M.; Wijkens, P.; Grove, D. M.; van Koten, G. Nature 1994, 372, 659. (b) van de Kuil, L. A.; Luitjes, J.; Grove, D. M.; Zwikker, J. W.; van der Linden, J . G. M.; Roel ofsen, A. M.; J enneskens, L. W.; Drenth, W.; van Koten, G. Organometallics 1994, 13, 468. (c) van de Kuil, L. A.; Grove, D. M.; Zwikker, J. W.; J enneskens, L. W.; Drenth, W.; van Koten, G. Chem. Mater. 1994, 8, 1675. (d) Donkervoort, J . G.; Vicario, J. L.; J astrzebski, J . T. B. H.; Cahiez, G.; van Koten, G. Recl. Trav. Chim. Pays-Bas 1996, 115, 547.

(8) (a) Sutter, J .-P.; Grove, D. M.; Beley, M.; Collin, J .-P.; Veldman, N.; Spek, A. L.; Sauvage, J .-P.; van Koten, G. Angew. Chem., Int. Ed. Engl. 1994, 33, 1282. (b) Steenwinkel, P.; J ames, S. L.; Grove, D. M.; Kooijman, H.; Spek, A. L.; van Koten, G. Organometallics 1997, 16, 513. (c) Lagunas, M.-C.; Gossage, R. A.; Spek, A. L.; van Koten, G. Organometallics, in press.

(9) Organometallic polymers derived from bispalladium complexes of a sulfur-containing analog of the dianionic ligand $\mathrm{C}_{2} \mathrm{~N}_{4}$, i.e., $\left[\mathrm{C}_{6}\left(\mathrm{CH}_{2-}\right.\right.$ $\left.\mathrm{SPh})_{4}-2,3,5,6\right]^{2-}$, have been reported; see: Loeb, S. J .; Shimizu, G. K. H. J . Chem. Soc., Chem. Commun. 1993, 1395.

\section{Scheme 1. Synthesis of the Tetraaminoaryl Dibromide 2 and of the Dimeric and Polymeric Organolithium Reagents 3, $4(R=H)$, and $7(R=$ $\left.\mathrm{CH}_{2} \mathrm{NMe}_{2}\right)^{\mathrm{a}}$}
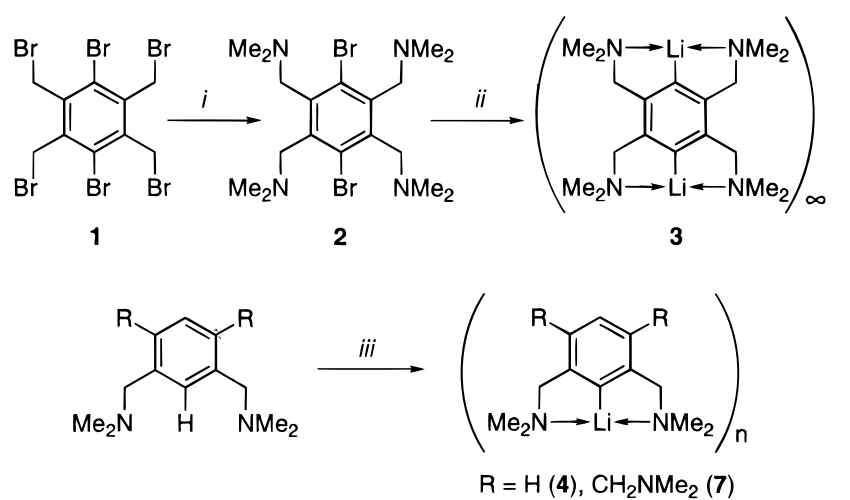

a Conditions: (i) $\mathrm{HNMe}_{2}$, THF. (ii) n-BuLi, $\mathrm{Et}_{2} \mathrm{O}$ or THF. (iii) n-BuLi, hexane.

presented, and the reactivity patterns are compared with those of related mononuclear NCN complexes. Some preliminary aspects of this work have recently been communicated. ${ }^{8 b}$

\section{Results}

The target complexes of this study are the silane and stannane of general formula [Me $3 \mathrm{M}_{2} \mathrm{C}_{6} \mathrm{H}_{3}\left(\mathrm{CH}_{2} \mathrm{NMe}_{2}\right)_{2}-$ 2,6\}] ( $\mathrm{M}=\mathrm{Si}(5), \mathrm{Sn}(6))$ and the dinuclear species [(Me3 M $\left.)_{2}-1,4-\left\{\mathrm{C}_{6}\left(\mathrm{CH}_{2} \mathrm{NMe}_{2}\right)_{4}-2,3,5,6\right\}\right]$ ( $\mathrm{M}=\mathrm{Si}(\mathbf{9}), \mathrm{Sn}$ (10)). The synthetic strategy involved in the synthesis of these silanes and stannanes is based on the preparation of the organolithium derivatives of the ligands NCN and $\mathrm{C}_{2} \mathrm{~N}_{4}$ (Scheme 1), followed by transmetalation of these reagents with suitable silicon and tin precursors (Scheme 2).

Synthesis of the Organolithium Species. To prepare the organodilithium derivative of $\mathrm{C}_{2} \mathrm{~N}_{4}$, [ $\mathrm{Li}_{2}$ 1,4-\{ $\left.\left.\mathrm{C}_{6}\left(\mathrm{CH}_{2} \mathrm{NMe}_{2}\right)_{4}-2,3,5,6\right\}\right]_{\infty}$ (3), a two-step procedure was developed (see Scheme 1). In the first step, nucleophilic amination of $\mathrm{Br}_{2}-1,4-\left\{\mathrm{C}_{6}\left(\mathrm{CH}_{2} \mathrm{Br}\right)_{4}-2,3,5,6\right.$ (1) with $\mathrm{HNMe}_{2}$ affords $\mathrm{Br}_{2}-1,4-\left\{\mathrm{C}_{6}\left(\mathrm{CH}_{2} \mathrm{NMe}_{2}\right)_{4}-2,3,5,6\right.$ (2). In the second step, a lithium-halogen exchange reaction of dibromide $\mathbf{2}$ with n-BuLi in $\mathrm{Et}_{2} \mathrm{O}$ selectively forms the dilithiated species $\mathbf{3}$. Complex $\mathbf{3}$ was identified as the dilithiated species by quenching of samples of the isol ated white solid with $\mathrm{H}_{2} \mathrm{O}$ and $\mathrm{D}_{2} \mathrm{O}$ and subsequent identification of the organic products as $\mathrm{C}_{6} \mathrm{H}_{2}\left(\mathrm{CH}_{2}\right.$ $\left.\mathrm{NMe}_{2}\right)_{4}-1,2,4,5^{10}$ and $\mathrm{C}_{6} \mathrm{D}_{2}\left(\mathrm{CH}_{2} \mathrm{NMe}_{2}\right)_{4}-1,2,4,5$, respectively. The direct precursors of the ligands NCN and $\mathrm{C}_{2} \mathrm{~N}_{4}$ are $\mathrm{C}_{6} \mathrm{H}_{4}\left(\mathrm{CH}_{2} \mathrm{NMe}_{2}\right)_{2}-1,3$ (1,3-bis[(dimethylamino)methyl ]benzene) and $\mathrm{C}_{6} \mathrm{H}_{2}\left(\mathrm{CH}_{2} \mathrm{NMe}_{2}\right)_{4}-1,2,4,5(1,2,4,5-$ tetrakis[(dimethylamino)methyl]benzene) for which an improved synthetic pathway has been developed. For $\mathrm{C}_{6} \mathrm{H}_{4}\left(\mathrm{CH}_{2} \mathrm{NMe}_{2}\right)_{2}-1,3$, this pathway proceeds through a Clark-E schweiler reductive alkylation of $\alpha, \alpha^{\prime}$-diamino$\mathrm{m}$-xylene with aqueous formaldehyde and formic acid (see Experimental Section). The known dimeric organolithium derivatives of $\mathrm{NCN}$ and $\mathrm{C}_{2} \mathrm{~N}_{4}$, namely, $\left[\mathrm{LiC}_{6} \mathrm{H}_{3}\left(\mathrm{CH}_{2} \mathrm{NMe}_{2}\right)_{2}-2,6\right]_{2}$ (4) and [ $\mathrm{Li}\left\{\mathrm{C}_{6} \mathrm{H}\left(\mathrm{CH}_{2} \mathrm{NMe}_{2}\right)_{4}-\right.$ $2,3,5,6\}]_{2}(\mathbf{7})$, were prepared as previously described. ${ }^{20,11 c}$

(10) (a) van der Zeijden, A. A. H.; van Koten, G. Recl. Trav. Chim. Pays-Bas 1988, 107, 431. (b) Smeets, W. J . J .; Spek, A. L.; van der Zeijden, A. A. H.; van Koten, G. Acta Crystallogr. 1987, C43, 1420. 
Scheme 2. Synthesis of the New Silanes 5 and 9 $(M=S i)$ and the Stannanes 6 and $10(M=S n)^{a}$

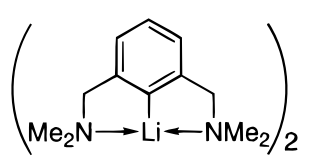

4
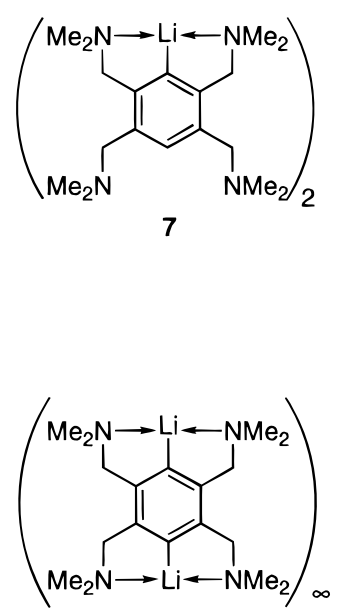

3

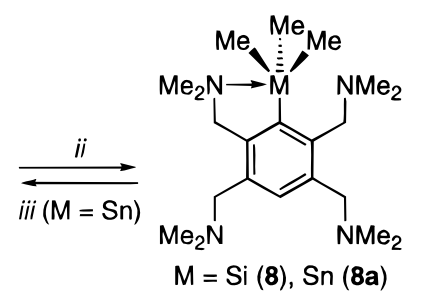

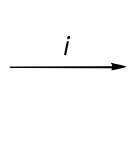

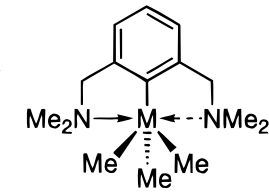

$M=\operatorname{Si}(5), \operatorname{Sn}(6)$

iv

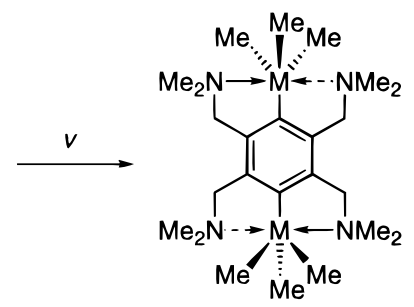

$\mathrm{M}=\mathrm{Si}(\mathbf{9}), \mathrm{Sn}$ (10) a Conditions: (i) $\mathrm{Me}_{3} \mathrm{SiOTf}$, hexane/THF or $\mathrm{Me}_{3} \mathrm{SnCl}, \mathrm{THF}$. (ii) $\mathrm{Me}_{3} \mathrm{SiOTf}, \mathrm{Et}_{2} \mathrm{O}$ or $\mathrm{Me}_{3} \mathrm{SnCl}$, THF. (iii) n-BuLi, hexane, -BuSnMes. (iv) n-BuLi, hexane followed by MesSiOTf, THF. (v) $\mathrm{Me}_{3} \mathrm{SiOTf}, \mathrm{Et}_{2} \mathrm{O}$ or $\mathrm{Me}_{3} \mathrm{SnCl}$, THF.

Synthesis of Silanes 5 and 9 and Stannanes 6 and 10. The desired monosilane $\left[\mathrm{Me}_{3} \mathrm{Si}\left\{\mathrm{C}_{6} \mathrm{H}_{3}\left(\mathrm{CH}_{2}-\right.\right.\right.$ $\left.\left.\left.\mathrm{NMe}_{2}\right)_{2}-2,6\right\}\right]$ (5) and monostannane $\left[\mathrm{Me}_{3} \mathrm{Sn}\left\{\mathrm{C}_{6} \mathrm{H}_{3}\left(\mathrm{CH}_{2-}\right.\right.\right.$ $\left.\left.\left.\mathrm{NMe}_{2}\right)_{2}-2,6\right\}\right]$ (6) can be prepared from transmetalation reactions of the organolithium species 4 in THF with $\mathrm{Me}_{3} \mathrm{SiOTf}$ (OTf $=\mathrm{OSO}_{2} \mathrm{CF}_{3}=$ triflate) and $\mathrm{Me}_{3} \mathrm{SnCl}$, respectively (Scheme 2 ).

The reaction of $\mathbf{4}$ with $\mathrm{Me}_{3} \mathrm{SiOTf}$ to form $\mathbf{5}$ is rapid (complete in $3 \mathrm{~min}$ at room temperature) and was shown to bequantitative by ${ }^{1} \mathrm{H}$ NMR spectroscopy. Monosilane $\mathbf{5}$ has been isolated from the reaction mixture as a colorless oil in $79 \%$ yield. Note that $\mathrm{Me}_{3} \mathrm{SiCl}$ failed to silylate lithium reagent $\mathbf{4}$, even after $24 \mathrm{~h}$ at room temperature. The reaction of 4 with $\mathrm{Me}_{3} \mathrm{SnCl}$ in $\mathrm{THF}$ affords selectively (as determined by ${ }^{1} \mathrm{H}$ NMR spectroscopy) the tin species $\left[\mathrm{Me}_{3} \mathrm{Sn}\left\{\mathrm{C}_{6} \mathrm{H}_{3}\left(\mathrm{CH}_{2} \mathrm{NMe}_{2}\right)_{2}-2,6\right\}\right]$ (6). After appropriate workup, complex $\mathbf{6}$ was isolated from the reaction mixture in $92 \%$ yield as a white solid.

The monosilane $\mathbf{5}$ and monostannane $\mathbf{6}$ have been characterized by NMR spectroscopy and elemental microanalysis. Some ${ }^{1 \mathrm{H}}$ and ${ }^{13} \mathrm{C}$ NMR spectroscopic data relevant to discussion of possible coordination of the $\mathrm{N}$-donor substituents to the group 14 center are summarized in Table 1. A characteristic feature of the ${ }^{1} \mathrm{H}$ and ${ }^{13} \mathrm{C}$ NMR spectra of 6 is the coupling of the ${ }^{117} \mathrm{Sn}$ and ${ }^{119} \mathrm{Sn}$ nuclei $(\mathrm{I}=1 / 2,7.68$ and $8.58 \%$ natural

(11) (a) J astrzebski, J . T. B. H.; van Koten, G.; Goubitz, K.; Arlen, C.; Pfeffer, M. J . Organomet. Chem. 1985, 246, C75. (b) Wehman, E.; J astrzebski, J . T. B. H.; Ernsting, J . M.; Grove, D. M.; van Koten, G. J . Organomet. Chem. 1988, 353, 145. (c) Steenwinkel, P.; J ames, S. L.; Grove, D. M.; Veldman, N.; Spek, A. L.; van Koten, G. Chem. Eur. J . 1996, 2, 1440. (d) Schlengermann, R.; Sieler, J .; J elonek, S.; HeyHawkins, E. Chem. Commun. 1997, 197. abundance, respectively) to the $\mathrm{H}$ and $\mathrm{C}$ atoms of the organic ligand array. For example, in the ${ }^{1} \mathrm{H}$ NMR spectrum of $6\left(\mathrm{CDCl}_{3}\right.$ solution) the $\mathrm{Me}_{3} \mathrm{Sn}$ group shows double satellites with coupling constant values of 51 and $53 \mathrm{~Hz}$.

The disilylated complex of $\mathrm{C}_{2} \mathrm{~N}_{4}$, namely, $\left[\left(\mathrm{Me}_{3} \mathrm{Si}\right)_{2-}\right.$ 1,4-\{ $\left.\left.\mathrm{C}_{6}\left(\mathrm{CH}_{2} \mathrm{NMe}_{2}\right)_{4}-2,3,5,6\right\}\right]$ (9), can be prepared by two different methods (Scheme 2). The first method involves reaction of the polymeric organodilithium species [ $\mathrm{Li}_{2}-$ 1,4- $\left.\left\{\mathrm{C}_{6}\left(\mathrm{CH}_{2} \mathrm{NMe}_{2}\right)_{4}-2,3,5,6\right\}\right]_{\infty}$ (3) with Me $\mathrm{S}_{3} \mathrm{SiOTf}$ in THF. This affords disilylated $\mathbf{9}$ in $93 \%$ yield. The second method for the preparation of $\mathbf{9}$ empl oys two successive monolithiation/monosilylation cycles, starting from lithium species 7.10 This method, which involves the formation of the monosilylated aryltetramine $\mathbf{8}$ as an intermediate product, afforded $\mathbf{9}$ in isolated yields of $59 \%$ after chromatographic purification. Earlier we have found that $\mathbf{8}$ is, through selective $\mathrm{C}-\mathrm{Si}$ bond activation and transmetalation reactions, a very useful precursor to unsymmetrical $\mathrm{M} \cdots \mathrm{M}^{\prime}$ heterobimetallic complexes of $\mathrm{C}_{2} \mathrm{~N}_{4} .{ }^{8 b}$ The characterization of complex 9 as a bis(silane) with a 1,4-phenylene bridge includes characteristic NMR data (see Table 1) and an X-ray crystallographic study (vide infra).

The bis(organotin) complex $\left[\left(\mathrm{Me}_{3} \mathrm{Sn}\right)_{2}-1,4-\left\{\mathrm{C}_{6}\left(\mathrm{CH}_{2-}\right.\right.\right.$ $\left.\left.\left.\mathrm{NMe}_{2}\right)_{4}-2,3,5,6\right\}\right](10)$ can be prepared by the reaction of the dilithio species 3 (prepared in situ from dibromide $\mathbf{2}$ with n-BuLi in THF) with $\mathrm{Me}_{3} \mathrm{SnCl}$. Complex $\mathbf{1 0}$ has been isolated as an air-stable white solid in 53\% yield. Note that this complex cannot be prepared in a twocycle process of monolithiation and monostannylation starting from organol ithium reagent $\mathbf{7}$ as described for the bis(silane) 9. The reaction of the intermediate monoorganotin complex [ $\left.\mathrm{Me}_{3} \mathrm{Sn}\left\{\mathrm{C}_{6} \mathrm{H}\left(\mathrm{CH}_{2} \mathrm{NMe}_{2}\right)_{4}-2,3,5,6\right\}\right]$ (8a) with n-BuLi did not result in aromatic deprotonation, but instead quantitative reformation of the organolithium reagent 7 occurred (Scheme 2 and Experimental Section). This reactivity of organotin(IV) compounds toward organolithium reagents has been described, for example, by Gielen and Tondeur. ${ }^{12}$ The characterization of complex $\mathbf{1 0}$ as a bis(stannane) with a 1,4-phenylene bridge includes characteristic NMR data (see Table 1) and an X-ray crystallographic study (vide infra).

Reactions of 5, 6, 9, and 10 with $\mathrm{Pd}(\mathrm{II})$ and $\mathrm{Pt}(\mathrm{II})$ Complexes. The reactivity of the new silanes $\mathbf{5}$ and $\mathbf{9}$ and the stannanes $\mathbf{6}$ and $\mathbf{1 0}$ as organyl group-transfer reagents has been tested using some divalent platinum group complexes as substrates. The organometallic products of these reactions, which result from both alkyl and aryl transfer, are summarized in Schemes 3 and 4; product characterization and product distributions were determined by ${ }^{1} \mathrm{H}$ and ${ }^{13} \mathrm{C}$ NMR spectroscopy.

The silanes 5 and 9 react rather slowly with $\mathrm{Pd}(\mathrm{OAC})_{2}$ (in $\mathrm{MeOH}, 10 \mathrm{~h}$ ). In analogous reactions, the stannanes 6 and 10 react significantly faster and the $\mathrm{Pd}(\mathrm{OAC})_{2}$ was consumed in $\sim 30 \mathrm{~min}$. In all four cases, after addition of excess $\mathrm{LiCl}$ and workup, one finds by ${ }^{1} \mathrm{H}$ and ${ }^{13} \mathrm{C} \mathrm{NMR}$ spectroscopy quantitative formation of either the mononuclear species $\left[\mathrm{PdCl}\left\{\mathrm{C}_{6} \mathrm{H}_{3}\left(\mathrm{CH}_{2} \mathrm{NMe}_{2}\right)_{2}-2,6\right\}\right]$ (11) ${ }^{13}$ (from complexes $\mathbf{5}$ and $\mathbf{6})$ or the dinuclear species $\left[(\mathrm{PdCl})_{2^{-}}\right.$

(12) Gielen, M.; Tondeur, Y. J . Organomet. Chem. 1981, 216, 371 and references therein.

(13) Grove, D. M.; van Koten, G.; Louwen, J . N.; Noltes, J . G.; Spek, A. L.; Ubbels, H. J . C. J . Am. Chem. Soc. 1982, 104, 6609. 
Table 1. Selected ${ }^{1} \mathrm{H}$ and ${ }^{13} \mathrm{C}$ NMR Data ${ }^{a}$ of the Silanes 5 and 9 and Stannanes 6 and 10 Together with Those of Their Free Ligand Precursors $\mathrm{C}_{6} \mathrm{H}_{4}\left(\mathrm{CH}_{2} \mathrm{NMe}_{2}\right)_{2}-1,3$ and $\mathrm{C}_{6} \mathrm{X}_{2}\left(\mathrm{CH}_{2} \mathrm{NMe}_{2}\right)_{4}-1,2,4,5(\mathrm{X}=\mathrm{H}, \mathrm{Br})$

\begin{tabular}{|c|c|c|c|c|c|c|}
\hline \multirow[b]{2}{*}{ compound } & \multicolumn{3}{|c|}{${ }^{1} \mathrm{H} N M R$} & \multicolumn{3}{|c|}{${ }^{13} \mathrm{C} N \mathrm{NMR}$} \\
\hline & $\overline{\mathrm{CH}_{2}}$ & $\mathrm{NMe}_{2}$ & $\mathrm{Me}_{3} \mathrm{M}\left({ }^{2} \mathrm{~J}_{\mathrm{SnH}}\right)^{\mathrm{d}}$ & $\overline{\mathrm{CH}_{2}\left({ }^{3} \mathrm{~J}_{\mathrm{SnH}}\right)^{\mathrm{d}}}$ & $\mathrm{NMe}_{2}$ & $\mathrm{Me}_{3} \mathrm{M}\left({ }^{1} \mathrm{~J} \mathrm{SnC}^{\mathrm{d}}\right.$ \\
\hline$(\mathrm{NCN}) \mathrm{H}^{\mathrm{b}}$ & 3.12 & 1.94 & & 64.1 & 45.2 & \\
\hline$\left[(\mathrm{NCN}) \mathrm{SiMe}_{3}\right](5)^{\mathrm{b}}$ & 3.52 & 2.14 & 0.38 & 64.9 & 45.3 & 3.3 \\
\hline$\left[(\mathrm{NCN}) \mathrm{SnMe}_{3}\right](\mathbf{6})^{\mathrm{b}}$ & 3.63 & 2.22 & $0.37(53,51)$ & $66.1(21)$ & 44.9 & $-3.4(371,355)$ \\
\hline$\left(\mathrm{C}_{2} \mathrm{~N}_{4}\right) \mathrm{H}_{2}^{\mathrm{b}}$ & 3.41 & 2.14 & & 61.0 & 45.5 & \\
\hline$\left(\mathrm{C}_{2} \mathrm{~N}_{4}\right) \mathrm{Br}_{2}^{\mathrm{c}}$ & 3.97 & 2.27 & & 59.7 & 45.4 & \\
\hline$\left[\left(\mathrm{C}_{2} \mathrm{~N}_{4}\right)\left(\mathrm{SiMe}_{3}\right)_{2}\right](\mathbf{9})^{\mathrm{c}}$ & 3.62 & 2.06 & 0.28 & 61.4 & 44.4 & 4.1 \\
\hline$\left[\left(\mathrm{C}_{2} \mathrm{~N}_{4}\left(\mathrm{SnMe} \mathrm{e}_{3}\right)_{2}\right](\mathbf{1 0})^{\mathrm{c}}\right.$ & 3.57 & 2.08 & $0.12(42)$ & $60.1(25)$ & 43.7 & $-2.2(356)$ \\
\hline
\end{tabular}

Scheme 3. Reactivity of Silane 5 and Stannane 6 toward $\mathrm{Pd}(\mathrm{OAC})_{2}$ and $\left[\mathrm{M}^{\prime} \mathrm{Cl}_{2}(\mathrm{COD})\right]\left(\mathrm{M}^{\prime}=\mathbf{P d}, \mathrm{Pt}\right)^{\mathrm{a}}$

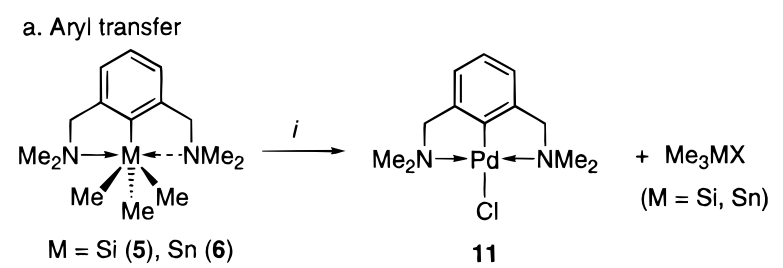

b. Methyl transfer

a Conditions: (i) $\mathrm{Pd}(\mathrm{OAC})_{2}, \mathrm{MeOH}$ followed by $\mathrm{LiCl}, \mathrm{MeOH}$ or $\left[\mathrm{PdCl}_{2}(\mathrm{COD})\right], \mathrm{CH}_{2} \mathrm{Cl}_{2}$. (ii) $\left[\mathrm{PtCl}_{2}(\mathrm{COD})\right], \mathrm{CH}_{2} \mathrm{Cl}_{2}$.

Scheme 4. Reactivity of Silane 9 and Stannane 10 toward $\mathrm{Pd}(\mathrm{OAC})_{2}$ and $\left[\mathrm{M}^{\prime} \mathrm{Cl}_{2}(\mathrm{COD})\right]\left(\mathrm{M}^{\prime}=\mathbf{P d}, \mathbf{P t}\right)^{\mathrm{a}}$

a. Aryl transfer

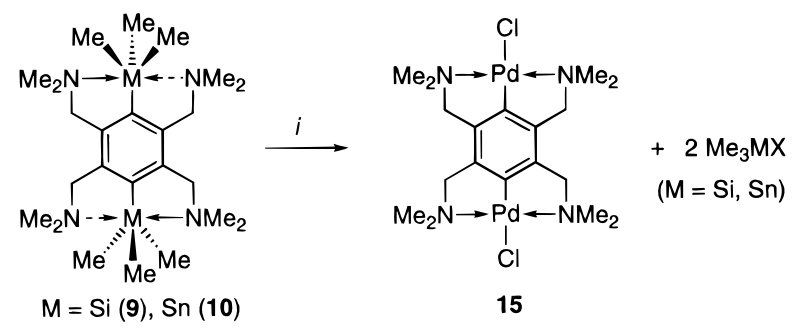

b. Methyl transfer

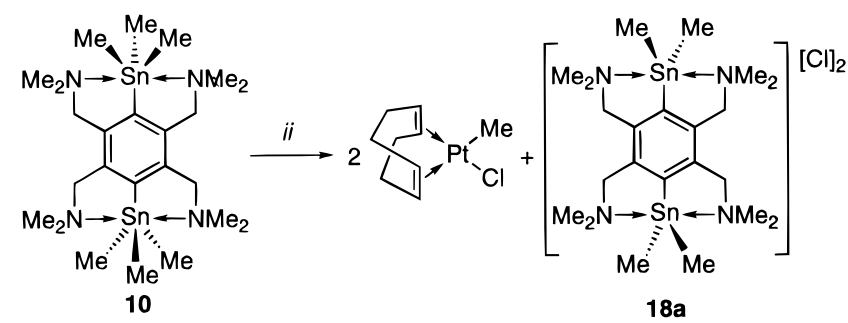

a Conditions: (i) 2 equiv of $\mathrm{Pd}(\mathrm{OAC})_{2}, \mathrm{MeOH}$ followed by $\mathrm{LiCl}, \mathrm{MeOH}$ or 2 equiv $\left[\mathrm{PdCl}_{2}(\mathrm{COD})\right], \mathrm{CH}_{2} \mathrm{Cl}_{2}$. (ii) 2 equiv $\left[\mathrm{PtCl}_{2}(\mathrm{COD})\right], \mathrm{CH}_{2} \mathrm{Cl}_{2}$.

1,4- $\left.\left\{\mathrm{C}_{6}\left(\mathrm{CH}_{2} \mathrm{NMe}_{2}\right)_{4}-2,3,5,6\right\}\right](\mathbf{1 5})^{8 b}$ (from complexes 9 and 10). These products result from aryl transfer from the silane or stannane to palladium, and since there is no formation of products resulting from $\mathrm{C}-\mathrm{H}$ activation, one can conclude that the $\mathrm{Me}_{3} \mathrm{M}$ group $(\mathrm{M}=\mathrm{Si}, \mathrm{Sn})$ has a strong directing effect in these reactions. ${ }^{14}$

(14) Steenwinkel, P.; Maunula, T.; van Koten, G., to be published.
Similar reactions of silanes $\mathbf{5}$ and $\mathbf{9}$ and stannanes $\mathbf{6}$ and 10 with the palladium(II) substrate $\left[\mathrm{PdCl}_{2}(\mathrm{COD})\right]$ (COD = cycloocta-1,5-diene) (instead of $\mathrm{Pd}(\mathrm{OAC})_{2}$ ) are in all cases slow and substrate conversion is only complete after $\sim 10 \mathrm{~h}$. The tin species $\mathbf{6}$ and $\mathbf{1 0}$ give rise, via aryl transfer, to aryl palladium complexes $\mathbf{1 1}$ and 15, respectively, together with traces of the methyl transfer product [PdCIMe(COD)]. ${ }^{15}$ Interestingly, also minor amounts of the ionic tin-containing compounds $14 \mathbf{a}^{16}$ and $\mathbf{1 8} \mathbf{a}$ (vide infra) are formed, the nature of which is discussed below in detail. The products of the reactions of silanes $\mathbf{5}$ and $\mathbf{9}$ with $\left[\mathrm{PdCl}_{2}(\mathrm{COD})\right]$ appear to be coordination complexes, but the identity of these materials has not been established; species resulting from $\mathrm{C}-\mathrm{Si}$ bond cleavage were not detected.

The silanes $\mathbf{5}$ and $\mathbf{9}$ did not react with the Pt(II) halide complex $\left[\mathrm{PtCl}_{2}(\mathrm{COD})\right]$. However, there is a slow reaction of this $\mathrm{Pt}(\mathrm{II})$ substrate with stannanes $\mathbf{6}$ and $\mathbf{1 0}$, and in both cases, after $48 \mathrm{~h}$ a white precipitate had formed. The ready solubility of these precipitates in water point to materials that probably have an ionic formulation. The NMR spectra of solutions of these precipitates in $\mathrm{D}_{2} \mathrm{O}$ show signals of the arylamine ligands $\mathrm{NCN}$ and $\mathrm{C}_{2} \mathrm{~N}_{4}$ for the products derived from 6 and $\mathbf{1 0}$, respectively, and of methyl groups bonded to tin. The ${ }^{1} \mathrm{H}$ NMR integral data and elemental microanalysis data are in accordance with these materials being ionic stannanes $\left[\mathrm{Me}_{2} \mathrm{Sn}\left\{\mathrm{C}_{6} \mathrm{H}_{3}\left(\mathrm{CH}_{2} \mathrm{NMe}_{2}\right)_{2}-2,6\right\}\right]^{+}-$ $\mathrm{Cl}^{-}(\mathbf{1 4 a})^{16}$ and $\left[\left(\mathrm{Me}_{2} \mathrm{Sn}\right)_{2}-1,4-\left\{\mathrm{C}_{6}\left(\mathrm{CH}_{2} \mathrm{NMe}_{2}\right)_{4}-2,3,5,6\right\}\right]^{2+}-$ $\left(\mathrm{Cl}^{-}\right)_{2}$ (18a) (see Schemes 3 and 4). These reactions of 6 and 10 with $\left[\mathrm{PtCl}_{2}(\mathrm{COD})\right]$ also afforded organoplatinum(II) species which remain dissolved in the reaction mixture. After workup we identified small amounts $(<5 \%)$ of products arising from aryl transfer, i.e., [ $\mathrm{PtCl}-$ $\left.\left\{\mathrm{C}_{6} \mathrm{H}_{3}\left(\mathrm{CH}_{2} \mathrm{NMe}_{2}\right)_{2}-2,6\right\}\right](\mathbf{1 2})^{13,17}$ (from stannane 6) and $\left[(\mathrm{PtCl})_{2}-1,4-\left\{\mathrm{C}_{6}\left(\mathrm{CH}_{2} \mathrm{NMe}_{2}\right)_{4}-2,3,5,6\right\}\right]$ (16) ${ }^{8 \mathrm{c}}$ (from 10). However, the principal Pt(II) species obtained with both $\mathbf{6}$ and $\mathbf{1 0}$ is [PtCl(Me)(COD)], 18 which is the product of methyl group transfer to platinum.

For identification purposes, the ionic complexes [ $\mathrm{Me}_{2}-$ $\left.\mathrm{Sn}\left\{\mathrm{C}_{6} \mathrm{H}_{3}\left(\mathrm{CH}_{2} \mathrm{NMe}_{2}\right)_{2}-2,6\right\}\right]^{+} X^{-}(\mathbf{1 4})$ and $\left[\left(\mathrm{Me}_{2} \mathrm{Sn}\right)_{2}-1,4-\right.$ $\left.\left\{\mathrm{C}_{6}\left(\mathrm{CH}_{2} \mathrm{NMe}_{2}\right)_{4}-2,3,5,6\right\}\right]^{2+}\left(\mathrm{X}^{-}\right)_{2}(\mathbf{1 8})$ were independently synthesized (see Scheme 5). Reaction of the neutral stannanes $\mathbf{6}$ and $\mathbf{1 0}$ with excess of $\mathrm{Me}_{3} \mathrm{SnCl}$ in $\mathrm{CH}_{2} \mathrm{Cl}_{2}$

(15) (a) Rudler-Chauvin, M.; Rudler, H.J . Organomet. Chem. 1977, 134, 115. (b) Rülke, R. E.; Ernsting, J . M.; Spek, A. L.; Elsevier, C. J .; van Leeuwen, P. W. N. M.; Vrieze, K. Inorg. Chem. 1993, 32, 5769.

(16) van Koten, G.; J astrzebski, J . T. B. H.; Noltes, J. G.; Spek, A. L.; Schoone, J . C. J . Organomet. Chem. 1978, 148, 233.

(17) Terheijden, J .; van Koten, G.; Muller, F.; Grove, D. M.; Vrieze, K.; Nielsen, E.; Stam, C. H. J . Organomet. Chem. 1986, 315, 401.

(18) (a) Clark, H. C.; Manzer, L. E. J . Organomet. Chem. 1973, 59, 411. (b) Dekker, G. P. C. M.; Buijs, A.; Elsevier, C. J .; Vrieze, K.; van Leeuwen, P. W. N. M.; Smeets, W.J .J .; Spek, A. L.; Wang, Y. F.; Stam, C. H. Organometallics 1992, 11, 1937. 
Scheme 5. Independent Synthesis of the Novel Ionic Species $14 b$ and $18 b$

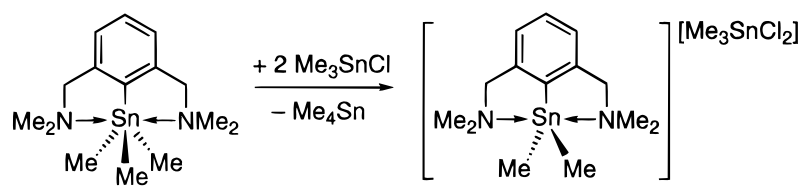

6

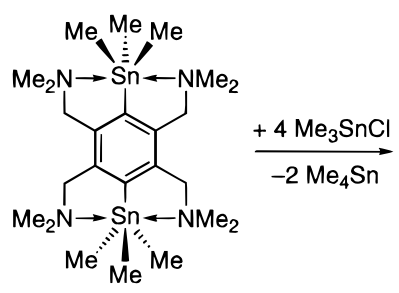

10

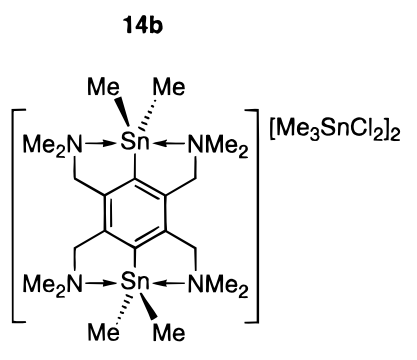

$18 b$

afforded, in a redistribution reaction, the complexes $\mathbf{1 4 b}$ (95\% yield) and $\mathbf{1 8 b}\left(59 \%\right.$ yield), with $\mathrm{X}=\left[\mathrm{Me}_{3} \mathrm{SnCl}_{2}\right]^{-}$ (vide infra). Complexes $\mathbf{1 4 b}$ and $\mathbf{1 8 b}$ are white solid hygroscopic complexes which readily crystallize from mixtures of $\mathrm{MeOH}$ and dibutyl ether.

The NMR spectra of $\mathbf{1 4 b}$ and $\mathbf{1 8 b}\left(\mathrm{D}_{2} \mathrm{O}\right)$ are similar to those of the chloro analogs $\mathbf{1 4 \mathbf { a } ^ { 1 6 }}$ and $\mathbf{1 8} \mathbf{a}$, respectively, with the exception that they also contain the extra resonance due to the $\left[\mathrm{Me}_{3} \mathrm{SnCl}_{2}\right]^{-}$counteranion. This anion affords $a^{1} \mathrm{H}$ NMR signal at $\sim 0.5 \mathrm{ppm}\left({ }^{2} \mathrm{~J} \mathrm{SnH}\right.$ $=66$ and $69 \mathrm{~Hz}$ ) and a ${ }^{13} \mathrm{C} \mathrm{NMR}$ signal at $\sim 1.5 \mathrm{ppm}$ ( $1 \mathrm{~J} \mathrm{SnC}=478$ and $499 \mathrm{~Hz}$ ). Prolonged drying of $\mathbf{1 4 b}$ in vacuo resulted in partial ( $15 \mathrm{~mol} \%)$ elimination of volatile $\mathrm{Me}_{3} \mathrm{SnCl}$, as deduced from a lower than expected intensity for the $\left[\mathrm{Me}_{3} \mathrm{SnCl}_{2}\right]^{-}$resonances in its ${ }^{1} \mathrm{H}$ NMR spectrum. This also hindered elemental microanalysis of this compound. An interesting aspect of complexes 14 and $\mathbf{1 8}$ is that the $\mathrm{CH}_{2} \mathrm{NMe}_{2}$ groups afford two singlet resonances in both the ${ }^{1} \mathrm{H}$ and ${ }^{13} \mathrm{C}$ NMR spectra. This equivalence of the $\mathrm{CH}_{2} \mathrm{NMe}_{2}$ groups is associated with chemical shifts and coupling data with $119,117 \mathrm{Sn}$ that indicate meridional $\mathrm{N}, \mathrm{C}, \mathrm{N}^{\prime}$-coordination of the NCN and $\mathrm{C}_{2} \mathrm{~N}_{4}$ ligands, whereby the tin(IV) centers are pentacoordinate (vide infra). ${ }^{16}$

Spectroscopic Aspects of Silanes 5 and 9 and Stannanes $\mathbf{6}$ and 10. The overall composition of the new organometallic silicon(IV) and tin(IV) species $\left[\mathrm{Me}_{3} \mathrm{M}\left\{\mathrm{C}_{6} \mathrm{H}_{3}\left(\mathrm{CH}_{2} \mathrm{NMe}_{2}\right)_{2}-2,6\right\}\right]$ ( $\mathrm{M}=\mathrm{Si}(5)$, Sn (6)) and $\left[\left(\mathrm{Me}_{3} \mathrm{M}\right)_{2}-1,4-\left\{\mathrm{C}_{6}\left(\mathrm{CH}_{2} \mathrm{NMe}_{2}\right)_{4}-2,3,5,6\right\}\right](\mathrm{M}=\mathrm{Si}(\mathbf{9}), \mathrm{Sn}$ (10)) could be readily established by standard spectroscopic and microanalytical techniques (see Experimental Section and above). However, because of the presence of potentially coordinating $\mathrm{N}$-donor centers in the $\mathrm{CH}_{2^{-}}$ $\mathrm{NMe}_{2}$ substituents of the $\mathrm{NCN}$ and $\mathrm{C}_{2} \mathrm{~N}_{4}$ ligands, we have examined the ${ }^{1} \mathrm{H}$ and ${ }^{13} \mathrm{C}$ NMR data carefully for evidence of possible $\mathrm{N} \rightarrow \mathrm{M}$ interactions. Data that allow direct comparison of complexes 5, 6, 9, and $\mathbf{1 0}$ with the arylamines $\mathrm{C}_{6} \mathrm{H}_{4}\left(\mathrm{CH}_{2} \mathrm{NMe}_{2}\right)_{2}-1,3$ and $\mathrm{C}_{6} \mathrm{H}_{2}\left(\mathrm{CH}_{2}-\right.$ $\left.\mathrm{NMe}_{2}\right)_{4}-1,2,4,5$, i.e., the precursors of the $\mathrm{NCN}$ and $\mathrm{C}_{2} \mathrm{~N}_{4}$ ligands, are collected in Table 1.

Compared to the free arylamines, the data for complexes 5, 6, 9, and $\mathbf{1 0}$ show that introduction of a silicon or a tin center into the organic cleft of $\mathrm{NCN}$ or $\mathrm{C}_{2} \mathrm{~N}_{4}$ provides in general a downfield shift of the ${ }^{1} \mathrm{H}$ and ${ }^{13} \mathrm{C}$ NMR resonances of the $\mathrm{CH}_{2} \mathrm{NMe}_{2}$ substituents. For example, the ${ }^{1} \mathrm{H}$ NMR resonances the $\mathrm{CH}_{2}$ groups in the

silicon and tin complexes 5 and $\mathbf{6}$ are $\sim 0.5 \mathrm{ppm}$ downfield to those of the free arylamine $\mathrm{C}_{6} \mathrm{H}_{4}\left(\mathrm{CH}_{2}\right.$ $\left.\mathrm{NMe}_{2}\right)_{2}-1,3$, and a somewhat smaller downfield shift of $\sim 0.3 \mathrm{ppm}$ is found for the $\mathrm{NMe}_{2}$ resonances. Although the ${ }^{13} \mathrm{C}$ NMR data of $\mathbf{5}$ and $\mathbf{6}$ show a similar downfield trend for the $\mathrm{CH}_{2}$ resonances, it is interesting to see that the chemical shifts of the $\mathrm{NMe}_{2}$ resonances are virtually identical to those of the free arylamines. As a general observation, one al so sees from Table 1 that the downfield shifts are more pronounced for the tin complexes $\mathbf{6}$ and $\mathbf{1 0}$ than for the anal ogous silicon species $\mathbf{5}$ and $\mathbf{9}$. Furthermore, relative to the free arylamines these downfield shifts arising from metal coordination are smaller for the dinuclear $\mathrm{C}_{2} \mathrm{~N}_{4}$ complexes of silicon (9) and tin (10) than for the mononuclear NCN complexes 5 and 6.

The solution NMR shift data in Table 1 for complexes 5, 6, 9, and $\mathbf{1 0}$ are consistent with some degree of intramolecular $\mathrm{N} \rightarrow \mathrm{M}$ interaction from the $\mathrm{CH}_{2} \mathrm{NMe}_{2}$ groups with the incorporated metal centers but in themselves are not particularly conclusive. Direct evidence of such coordination is in theory possible through observation of satellites arising from coupling to ${ }^{29} \mathrm{Si}\left(\mathrm{I}=1 / 2,4.67 \%\right.$ natural abundance) and ${ }^{117} \mathrm{Sn}$ (I $=1 / 2,7.68 \%$ natural abundance) and ${ }^{119} \mathrm{Sn}(I=1 / 2,8.58 \%$ natural abundance) in both ${ }^{1 \mathrm{H}}$ and ${ }^{13} \mathrm{C}$ NMR spectra. However, the only coupling observed was of tin to the $\mathrm{CH}_{2}$ resonances $\left({ }^{1} \mathrm{H}\right.$ and $\left.{ }^{13} \mathrm{C} \mathrm{NMR}\right)$ in complexes 6 and 10; since this coupling could arise from a coupling pathway through the aromatic skel eton, ${ }^{4 d}$ these data are also not conclusive for $\mathrm{N} \rightarrow \mathrm{M}$ coordination. Variabletemperature ${ }^{1} \mathrm{H}$ and ${ }^{13} \mathrm{C}$ NMR spectra of the new silanes $\mathbf{5}$ and $\mathbf{9}$ and stannanes $\mathbf{6}$ and $\mathbf{1 0}$ al so did not afford any further evidence for $\mathrm{N} \rightarrow \mathrm{M}$ coordination.

To further investigate $\mathrm{N} \rightarrow \mathrm{M}$ coordination, we have also measured ${ }^{29} \mathrm{Si}$ NMR spectra of $\mathbf{5}$ and $\mathbf{9}$ and ${ }^{119} \mathrm{Sn}$ NMR spectra of complexes $\mathbf{6}$ and $\mathbf{1 0}$. Silanes $\mathbf{5}$ and $\mathbf{9}$ show in their ${ }^{29} \mathrm{Si} N \mathrm{NMR}$ spectra $\left(\mathrm{C}_{6} \mathrm{D}_{6}\right)$ resonances at -7.7 and $-11.2 \mathrm{ppm}$, respectively, that are significantly more highfield than those of silanes $\mathrm{SiMe}_{3}\left(\mathrm{C}_{6} \mathrm{H}_{5}\right)^{19}$ and [SiMe $\left.\left.3 \mathrm{C}_{6} \mathrm{H}_{4}\left(\mathrm{CH}_{2} \mathrm{NMe}_{2}\right)-2\right\}\right]^{20}$ (see Table 2). These highfield shifts point to increased electron density at the silicon centers. Since it is known that substitution of the aromatic ring of aryltrimethylsilanes with alkyl donor groups only leads to minor changes in ${ }^{29} \mathrm{Si} N \mathrm{NR}$ chemical shifts (up to $\sim 1 \mathrm{ppm}$ ), ${ }^{19}$ it can be concluded that $\mathbf{5}$ and $\mathbf{9}$ do have some inteaction of one (or two) $\mathrm{CH}_{2} \mathrm{NMe}_{2}$ donor substituent(s) with the silicon center. Although the highfield shifts for $\mathbf{5}$ and $\mathbf{9}$ are small, they are consistent with the trend found in ${ }^{29} \mathrm{Si}$ NMR data for hypercoordinate silicon complexes. ${ }^{5 a}$ From the fact that the ${ }^{1} \mathrm{H}$ and ${ }^{13} \mathrm{C}$ NMR data of silanes 5 and $\mathbf{9}$ show the complexes to be symmetrical with equivalent $\mathrm{CH}_{2-}$ $\mathrm{NMe}_{2}$ donor substituents, it is likely that there is a fast equilibrium involving coordination and decoordination of one or both of the $\mathrm{N}$-donor groups to silicon in these species.

In a similar way, stannanes $\mathbf{6}$ and $\mathbf{1 0}$ show in their ${ }^{119} \mathrm{Sn}$ NMR spectra $\left(\mathrm{C}_{6} \mathrm{D}_{6}\right)$ resonances at -86.9 and $-107.0 \mathrm{ppm}$, respectively, that are significantly more highfield than those of stannanes $\mathrm{SnMe}_{3}\left(\mathrm{C}_{6} \mathrm{H}_{5}\right)^{21}$ and

(19) Williams, E. A.; Cargioli, J . D. In Annual Reports on NMR Spectroscopy; Webb, G. A., Ed; Academic Press: New York, 1979; Vol. $9, \mathrm{p} 221$.

(20) Helmer, B. J .; West, R.; Corriu, R. J . P.; Poirier, M.; Royo, G.; de Saxce, A. J . Organomet. Chem. 1983, 251, 295. 
Table 2. ${ }^{29} \mathrm{Si}\left(59.6 \mathrm{MHz}\right.$ ) and ${ }^{119} \mathrm{Sn}$ NMR (75 MHz) Data for Some Aryl/alkylsilanes

\begin{tabular}{|c|c|c|}
\hline compound & $\delta\left({ }^{29} \mathrm{Si}\right)$ & solvent \\
\hline $\begin{array}{l}\mathrm{SiMe}_{3}\left(\mathrm{C}_{6} \mathrm{H}_{5}\right) \\
\mathrm{SiMe}_{3}\left(\mathrm{C}_{6} \mathrm{H}_{5}\right) \\
{\left[\mathrm{SiMe}_{3}\left\{\mathrm{C}_{6} \mathrm{H}_{4}\left(\mathrm{CH}_{2} \mathrm{NMe}_{2}\right)-2\right\}\right]} \\
{\left[\mathrm{SiMe}_{3}\left\{\mathrm{C}_{6} \mathrm{H}_{3}\left(\mathrm{CH}_{2} \mathrm{NMe}_{2}\right)-2,6\right\}\right](\mathbf{5})} \\
{\left[\left(\mathrm{SiMe}_{3}\right)_{2}\left\{\mathrm{C}_{6}\left(\mathrm{CH}_{2} \mathrm{NMe}_{2}\right)-2,3,5,6\right\}\right](\mathbf{9})}\end{array}$ & $\begin{array}{r}-4.5 \\
-4.1 \\
-4.9 \\
-7.7 \\
-11.2\end{array}$ & $\begin{array}{l}\mathrm{C}_{6} \mathrm{D}_{6} \\
\mathrm{CDCl}_{3} \\
\mathrm{CDCl}_{3} \\
\mathrm{C}_{6} \mathrm{D}_{6} \\
\mathrm{C}_{6} \mathrm{D}_{6}\end{array}$ \\
\hline compound & $\delta$ (119Sn) & solvent \\
\hline $\begin{array}{l}\mathrm{SnMe}_{3}\left(\mathrm{C}_{6} \mathrm{H}_{5}\right) \\
{\left[\mathrm{SnMe}_{3}\left\{\mathrm{C}_{10} \mathrm{H}_{6} \mathrm{NMe}_{2}-8\right\}\right]} \\
{\left[\mathrm{SnMe}_{3}\left\{\mathrm{C}_{6} \mathrm{H}_{4}\left(\mathrm{CH}_{2} \mathrm{NMe} \mathrm{e}_{2}\right)-2\right\}\right]} \\
{\left[\mathrm{SnMe}_{2} \mathrm{C}_{6} \mathrm{H}_{4}\left(\mathrm{CH}_{2} \mathrm{NMe}_{2}\right)-2\right] \mathrm{Br}} \\
{\left[\mathrm{SnMe}_{3}\left\{\mathrm{C}_{6} \mathrm{H}_{3}\left(\mathrm{CH}_{2} \mathrm{NMe}_{2}\right)-2,6\right\}\right](\mathbf{6})} \\
{\left[\left(\mathrm{SnMe}_{3}\right)_{2}\left\{\mathrm{C}_{6}\left(\mathrm{CH}_{2} \mathrm{NMe}_{2}\right)-2,3,5,6\right\}\right](\mathbf{1 0})} \\
{\left[\mathrm{SnMe}_{2}\left\{\mathrm{C}_{6} \mathrm{H}_{3}\left(\mathrm{CH}_{2} \mathrm{NMe}_{2}\right)-2,6\right\}\right]\left[\mathrm{Me}_{3} \mathrm{SnCl}_{2}\right](\mathbf{1 4 b})} \\
{\left[\left(\mathrm{SnMe}_{2}\right)_{2}\left\{\mathrm{C}_{6}\left(\mathrm{CH}_{2} \mathrm{NMe}_{2}\right)-2,3,5,6\right\}\right]\left[\mathrm{Me}_{3} \mathrm{SnCl}_{2}\right]_{2}(\mathbf{1 8 b})}\end{array}$ & $\begin{array}{l}-24.1 \\
-46.7 \\
-50.0 \\
-50.0 \\
-86.9 \\
-107.0 \\
72.0(\mathrm{br})^{\mathrm{a}} \text { and } 34.1^{\mathrm{b}} \\
53.6(\mathrm{br})^{\mathrm{a}} \text { and } 35.2^{\mathrm{b}}\end{array}$ & $\begin{array}{l}\mathrm{C}_{6} \mathrm{D}_{6} \\
\mathrm{C}_{6} \mathrm{D}_{5} \mathrm{CD}_{3} \\
\mathrm{C}_{6} \mathrm{D}_{5} \mathrm{CD}_{3} \\
\mathrm{C}_{6} \mathrm{D}_{5} \mathrm{CD}_{3} \\
\mathrm{C}_{6} \mathrm{D}_{6} \\
\mathrm{C}_{6} \mathrm{D}_{6} \\
\mathrm{CD}_{3} \mathrm{OD} \\
\mathrm{CD}_{3} \mathrm{OD}\end{array}$ \\
\hline
\end{tabular}

a Chemical shift of the cation. ${ }^{\mathrm{b}}$ Chemical shift of the anion, $\left[\mathrm{Me}_{3} \mathrm{SnCl}_{2}\right]^{-}$.

[SnMe $\left.{ }_{3}\left\{\mathrm{C}_{6} \mathrm{H}_{4}\left(\mathrm{CH}_{2} \mathrm{NMe}_{2}\right)-2\right\}\right]^{22}$ (see Table 2) and that clearly indicate the presence of $\mathrm{N}$-donor coordination of the $\mathrm{CH}_{2} \mathrm{NMe}_{2}$ groups to the metal center in these new stannanes. From examination of ${ }^{119} \mathrm{Sn} \mathrm{NMR}$ data for the series $\mathrm{SnMe}_{3}\left(\mathrm{C}_{6} \mathrm{H}_{5}\right),{ }^{21}\left[\mathrm{SnMe} \mathrm{e}_{3}\left\{\mathrm{C}_{10} \mathrm{H}_{6} \mathrm{NMe}_{2}-8\right\}\right]\left(\mathrm{C}_{10} \mathrm{H}_{6}-\right.$ $\mathrm{NMe}_{2}=8$-(dimethylamino)-1-naphthyl), ${ }^{23}\left[\mathrm{SnMe}_{3}\left\{\mathrm{C}_{6} \mathrm{H}_{4-}\right.\right.$ $\left.\left.\left(\mathrm{CH}_{2} \mathrm{NMe}_{2}\right)-2\right\}\right],{ }^{22}$ [SnMe $\left.{ }_{3}\left\{\mathrm{C}_{6} \mathrm{H}_{3}\left(\mathrm{CH}_{2} \mathrm{NMe}_{2}\right)_{2}-2,6\right\}\right]$ (6), and $\left[\left(\mathrm{SnMe}_{3}\right)_{2}\left\{\mathrm{C}_{6}\left(\mathrm{CH}_{2} \mathrm{NMe}_{2}\right)_{4}-2,3,5,6\right\}\right]$ (10), in which the resonance of the tin nucleus shifts upfield from -24.1 to $-107.0 \mathrm{ppm}$ (Table 2), we conclude that in complexes $\mathbf{6}$ and $\mathbf{1 0}$ the tin(IV) centers are likely to be six-coordinate, rather than five-coordinate, with both $\mathrm{CH}_{2} \mathrm{NMe}_{2}$ donor substituents involved in $\mathrm{N} \rightarrow \mathrm{Sn}$ interactions on the NMR time scale. It has been proposed that the enhanced reactivity of $\mathrm{Sn}-\mathrm{C}$ bonds in tetraorganotin compounds containing $\mathrm{C}, \mathrm{N}$-chelating ligands is a result of this type of intramolecular $\mathrm{N} \rightarrow$ Sn coordination. 22,23

Solid-State Structures of $\mathbf{9}, 10$, and $18 \mathrm{~b}$. As shown above, the NMR data of silanes $\mathbf{5}$ and $\mathbf{9}$ and stannanes $\mathbf{6}$ and $\mathbf{1 0}$ are indicative of various degrees of intramolecular $\mathrm{N} \rightarrow \mathrm{M}$ coordination in solution. To further investigate the nature of such interactions in the solid state, $\mathrm{X}$-ray crystal structures of representative complexes, namely, the bis(silane) [(SiMes $)_{2}-1,4-\mathrm{C}_{6}\left(\mathrm{CH}_{2^{-}}\right.$ $\left.\left.\mathrm{NMe}_{2}\right)_{4}-2,3,5,6\right](\mathbf{9})$, the bis(stannane) [( $\left.\mathrm{SnMe}_{3}\right)_{2}-1,4-$ $\left.\mathrm{C}_{6}\left(\mathrm{CH}_{2} \mathrm{NMe}_{2}\right)_{4}-2,3,5,6\right](\mathbf{1 0})$, and the ionic bis(stannane) $\left.\left[\left(\mathrm{Me}_{2} \mathrm{Sn}\right)_{2-1,4-} \mathrm{C}_{6}\left(\mathrm{CH}_{2} \mathrm{~N} \mathrm{Me}_{2}\right)_{4}-2,3,5,6\right\}\right]^{2+}\left(\left[\mathrm{Me}_{3}-\right.\right.$ $\left.\left.\mathrm{SnCl}_{2}\right]^{-}\right)_{2}(\mathbf{1 8 b})$, have been carried out (Figures 2-4, respectively). Selected geometrical details of complexes $\mathbf{9}, \mathbf{1 0}$, and $\mathbf{1 8 b}$ are collected in Table 3. Crystal data of these complexes are collected in Table 4.

The molecular geometry of bis(silane) 9 (Figure 2) shows the $\mathrm{C}_{2} \mathrm{~N}_{4}$ ligand functioning as a bridge between two $\mathrm{SiMe}_{3}$ groups. The two silicon centers have identical coordination spheres as a result of a crystallographic center of symmetry positioned at the center of the aromatic ring and the intramolecular $\mathrm{Si}(1) \cdots \mathrm{Si}(1) \mathrm{A}$ distance is 6.6403(6) A. The silicon(IV) center forms four $\sigma$-bonds with the three methyl groups and a $\mathrm{C}_{\text {ipso }}$ atom (C(1)) of the bridging $\mathrm{C}_{2} \mathrm{~N}_{4}$ ligand. Furthermore, the silicon center has an interaction with one of the two available o- $\mathrm{CH}_{2} \mathrm{NMe}_{2}$ groups with the $\mathrm{N}(2)-\mathrm{Si}(1)$ bond

(21) Wrackmeyer, B. In Annual Reports on NMR Spectroscopy; Webb, G. A., Ed; Academic Press: New York, 1985; Vol 16, p 73.

(22) J astrzebski, J . T. B. H.; Grove, D. M.; Boersma, J .; van Koten, G.; Ernsting, J . M. Magn. Reson. Chem. 1991, 29, 25.

(23) Dawoodi, Z.; Eaborn, C.; Pidcock, A. J . Organomet. Chem. 1979, 170,95 and references therein.

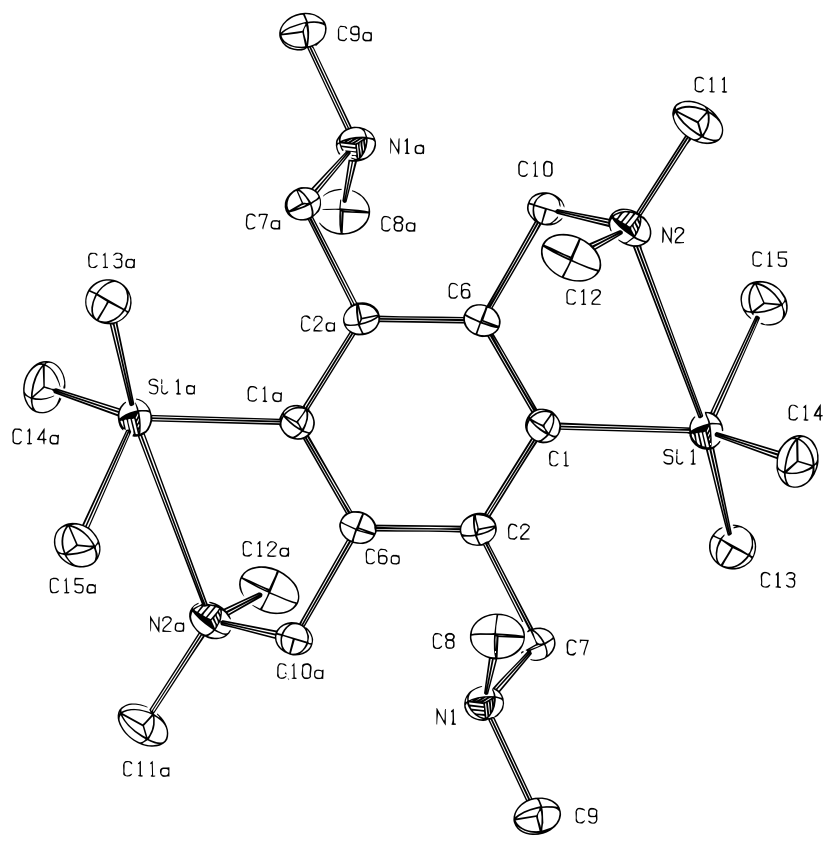

Figure 2. ORTEP drawing ( $50 \%$ probability atomic displacement ellipsoids) of [ $\left(\mathrm{Me}_{3} \mathrm{Si}\right)_{2}-1,4-\left\{\mathrm{C}_{6}\left(\mathrm{CH}_{2} \mathrm{NMe}_{2}\right)_{4^{-}}\right.$ $2,3,5,6\}]$ (9). Hydrogen atoms have been omitted for clarity.

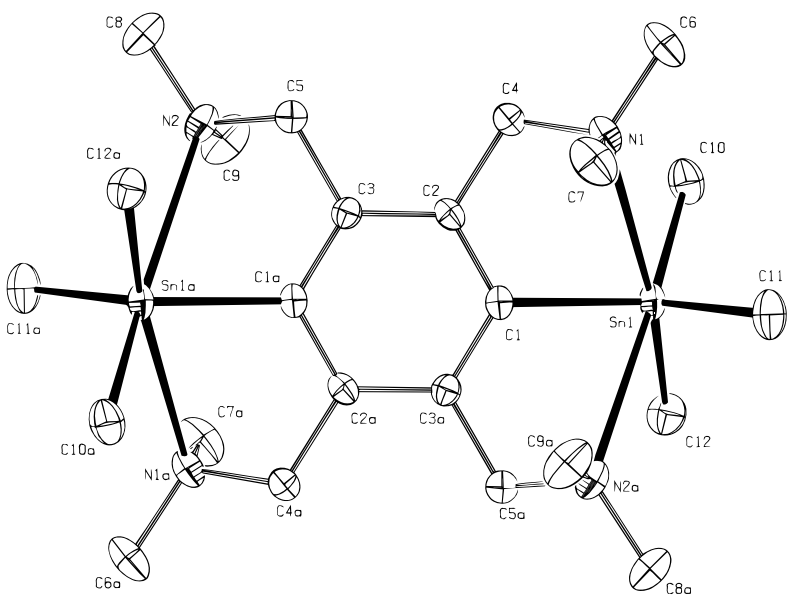

Figure 3. ORTEP drawing ( $50 \%$ probability atomic displacement ellipsoids) of [(M $\left.e_{3} \mathrm{Sn}\right)_{2}-1,4-\left\{\mathrm{C}_{6}\left(\mathrm{CH}_{2} \mathrm{NM} \mathrm{e}_{2}\right)_{4}-\right.$ $2,3,5,6\}](\mathbf{1 0})$. Hydrogen atoms have been omitted for clarity.

distance being 3.0403(12) $\AA$, and this is substantially smaller then the sum of the van der Waals radii of nitrogen and silicon (3.65 $\AA$ ). As a consequence of this 

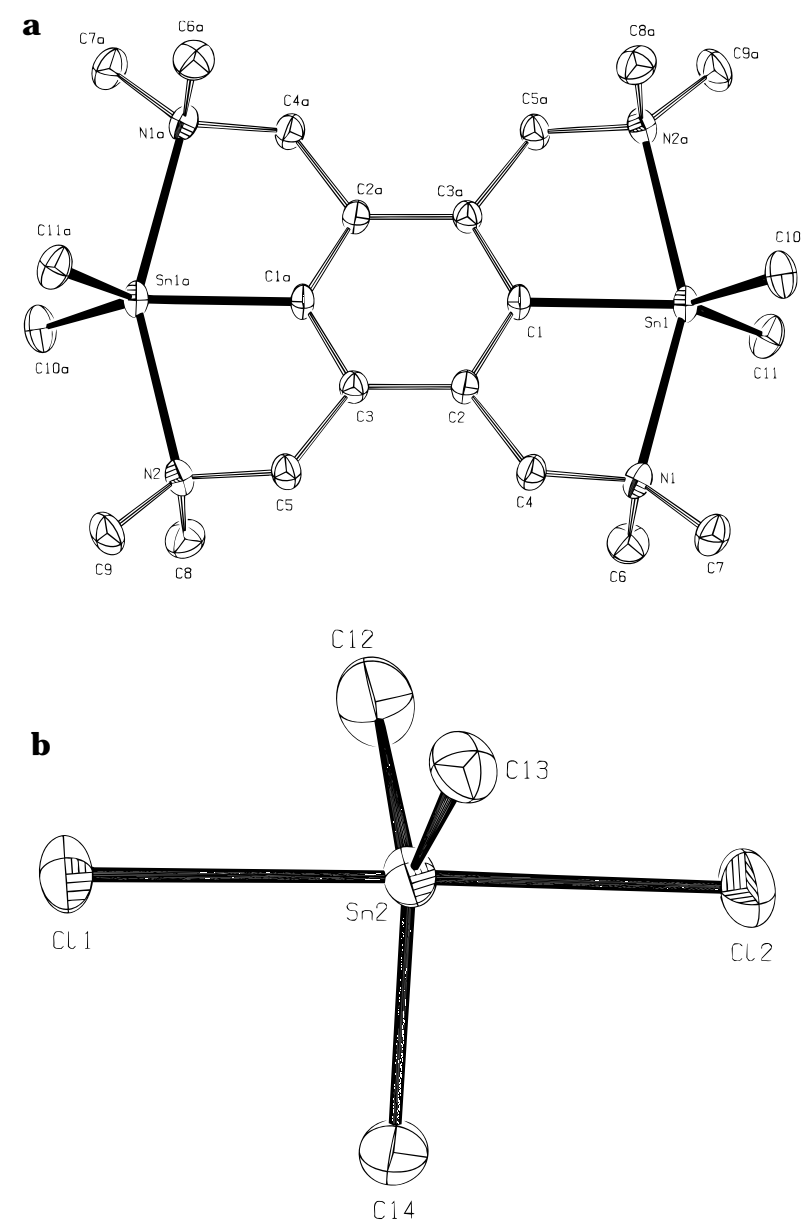

Figure 4. ORTEP drawing (50\% probability atomic displacement ellipsoids) of the complex cation of bis(stannane) 18b, $\left[\left(\mathrm{Me}_{2} \mathrm{Sn}\right)_{2}-1,4-\left\{\mathrm{C}_{6}\left(\mathrm{CH}_{2} \mathrm{NMe}_{2}\right)_{4}-2,3,5,6\right\}\right]^{2+}$ (a) and of the complex counterion, $\left[\mathrm{Me}_{3} \mathrm{SnCl}_{2}\right]^{-}$(b). Hydrogen atoms and one symmetry-related anion have been omitted for clarity.

interaction, the organyl groups on silicon are moved away from a true tetrahedral geometry (see Table 3) and the $\mathrm{Si}-\mathrm{Me}$ bond $\mathrm{Si}(1)-\mathrm{C}(13)$ is slightly longer than the other $\mathrm{Si}-\mathrm{Me}$ bonds $\mathrm{Si}(1)-\mathrm{C}(14)$ and $\mathrm{Si}(1)-\mathrm{C}(15)$. These parameters indicate that the silicon center may be regarded as being pentacoordinate ${ }^{4 c, 5}$ with the geometry being best described as capped tetrahedral with the $\mathrm{N}$-donor atom capping a face defined by $\mathrm{C}(1)$ and the two methyl groups bonded by $\mathrm{C}(14)$ and $\mathrm{C}(15)$. As a result of the $\mathrm{N}$-donor coordination, the silicon center can be seen to participate in a puckered five-membered chelate ring. This ring has an overall envel ope form with the $\mathrm{N}$-donor atom positioned out of the plane defined by the aromatic ring. Furthermore, there are slight distortions involving the central aromatic ring, which can be considered to have a twisted chair conformation. This is reflected in the individual deviations ( $\pm 0.021(1) \AA$ ) of the ring atoms from the least-squares plane of the aromatic ring and the out of plane angle of the $\mathrm{C}_{\mathrm{ipso}}-\mathrm{Si}$ bond in $\mathbf{9}\left(12.94(5)^{\circ}\right)$ with this least-squares plane.

The molecular geometry of $\mathbf{1 0}$, depicted in Figure 3 , shows this complex to be a bis(stannane) in which, as a consequence of a crystall ographic center of inversion at the center of the bridging aromatic ring, there are two identical six-coordinate tin(IV) centers separated by an

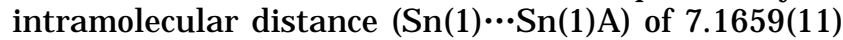
$\AA$. Each tin center has a distorted octahedral ligand array that arises from bonding interactions with the $\mathrm{C}_{\mathrm{ipso}}$ atom (C(1)) of the bridging phenylene group, the three methyl groups and the $\mathrm{N}$-donor atoms of two (ortho) $\mathrm{CH}_{2} \mathrm{NMe}_{2}$ substituents. The $\mathrm{N}$-donor groups are bonded in a cis fashion, which results in a pseudofacial $\mathrm{N}, \mathrm{C}, \mathrm{N}^{\prime}$-coordination mode of the aromatic ligand system. Probably as a result of the trans-coordinated $\mathrm{CH}_{2} \mathrm{NMe}_{2}$ groups, the $\mathrm{Sn}(1)-\mathrm{C}(10)$ and $\mathrm{Sn}(1)-\mathrm{C}(12)$ bonds are slightly longer than the $S n(1)-C(11)$ bond. Due to the pseudofacial coordination mode of each $\mathrm{N}, \mathrm{C}, \mathrm{N}^{\prime}$-coordination moiety, there is a slight distortion of the planarity of the central aromatic ring in the direction of a chair conformation. This is illustrated by the individual deviations ( $\pm 0.014(3) \AA$ ) of the ring $C$ atoms from the least-squares plane of the aromatic ring. Furthermore, the angle between the $\mathrm{C}_{\text {ipso }}-\mathrm{Sn}$ bond and this plane is 9.15(9) ${ }^{\circ}$. The interbond angles involving tin (see Table 3 ) show that the coordination geometry of the hexacoordinate tin(IV) center is probably not well suited for a description based on a distorted octahedral geometry but, in fact, may be better described as bicapped tetrahedral with the $\mathrm{N}$-donor atoms of two $\mathrm{CH}_{2} \mathrm{NMe}_{2}$ groups capping the two trigonal faces defined by $\mathrm{C}(1)$, $\mathrm{C}(10)$, and $\mathrm{C}(11)$ and by $\mathrm{C}(1), \mathrm{C}(11)$, and $\mathrm{C}(12)$.

The molecular geometry of $\mathbf{1 8 b}$, depicted in Figure 4, shows it to be an ionic species based on two $\left[\mathrm{Me}_{3} \mathrm{SnCl}_{2}\right]^{-}$ anions and a separate complex dication that contains a central bimetalated aromatic ring with two tin(IV) centers at an intramolecular $\mathrm{Sn}(1) \cdots \mathrm{Sn}(1) \mathrm{A}$ distance of $6.9281(10) \AA$. The tin atoms are identical and have a trigonal-bipyramidal ligand array arising from meridional $\mathrm{N}, \mathrm{C}, \mathrm{N}^{\prime}$-coordination of the aryl ligand in combination with two mutually trans bonded methyl groups. The two N-donor groups coordinated to each tin center afford a $\mathrm{N}-\mathrm{Sn}-\mathrm{N}$ bond angle of $152.05(7)^{\circ}$. Unlike the situation in complexes $\mathbf{9}$ and $\mathbf{1 0}$, the central aromatic ring of $\mathbf{1 8 b}$ is planar within the standard deviation (individual deviations of the ring $C$ atoms from the leastsquares plane of the aromatic ring: $\pm 0.000(3) \AA$ ) and the $\mathrm{Sn}$ atoms are located in the plane of this bridging phenylene moiety. The anion of the ionic species $\mathbf{1 8 b}$, $\left[\mathrm{Me}_{3} \mathrm{SnCl}_{2}\right]^{-}$, also has a tin(IV) atom with a trigonalbipyramidal coordination geometry. Here the methyl groups are in the meridional plane with interbond angles lying cl ose to $120^{\circ}$, and the $\mathrm{Cl}-\mathrm{Sn}-\mathrm{Cl}$ bond angle is close to $180^{\circ}$.

\section{Discussion}

We have shown that arylsilanes and -stannanes with potentially coordinating $\mathrm{CH}_{2} \mathrm{NMe}_{2}$ substituents are synthetically accessible through transmetalation reactions of the corresponding aryllithium reagents with suitable trimethyl chloride (Sn) and triflate (Si) derivatives of the group 14 (IVB) metals silicon and tin.

Organolithium Compounds. In our group, we have a general interest in the structure and reactivity of aryllithium compounds in which the lithium atoms are coordinated intramolecularly by suitable donor substituents, ortho positioned on the aromatic ring. In many previous studies of metal NCN complexes, the organol ithium derivative $\mathbf{4}$ was prepared by a lithiumhalogen exchange reaction of $\mathrm{C}_{6} \mathrm{H}_{3} \mathrm{Br}\left(\mathrm{CH}_{2} \mathrm{NMe}_{2}\right)_{2}-2,6$ with metallic lithium in $\mathrm{Et}_{2} \mathrm{O}$ and isolated as the pure solvent-free material by extraction and recrystallization from alkane solvents. In this study, we present an 
Table 3. Selected Bond Distances $(\AA)$ and Interbond and Dihedral Angles (deg) for 9, 10, and 18ba

\begin{tabular}{|c|c|c|c|c|c|}
\hline \multicolumn{2}{|c|}{ bond distances } & \multicolumn{2}{|c|}{ bond angles } & \multicolumn{2}{|c|}{ dihedral angles } \\
\hline \multicolumn{6}{|c|}{ Compound $\mathbf{9}^{b}$} \\
\hline $\mathrm{Si}(1)-C(1)$ & $1.9079(12)$ & $C(1)-S i(1)-C(13)$ & $107.27(7)$ & $C(1)-C(2)-C(6) A-C(1) A$ & $-6.14(19)$ \\
\hline $\mathrm{Si}(1)-\mathrm{C}(13)$ & 1.8891(19) & $\mathrm{C}(1)-\mathrm{Si}(1)-\mathrm{C}(14)$ & $114.81(7)$ & $C(2)-C(1)-C(6)-C(2) A$ & $-5.94(18)$ \\
\hline $\mathrm{Si}(1)-\mathrm{C}(14)$ & $1.8723(14)$ & $\mathrm{C}(1)-\mathrm{Si}(1)-\mathrm{C}(15)$ & $114.45(7)$ & $C(6)-C(1)-C(2)-C(6) A$ & $5.96(18)$ \\
\hline $\mathrm{Si}(1)-\mathrm{C}(15)$ & $1.8722(19)$ & $\mathrm{C}(13)-\mathrm{Si}(1)-\mathrm{C}(14)$ & $109.04(8)$ & $\mathrm{Si}(1)-C(1)-C(2)-C(6) A$ & $-162.96(10)$ \\
\hline $\mathrm{Si}(1)-N(2)$ & $3.0403(12)$ & $\mathrm{C}(13)-\mathrm{Si}(1)-\mathrm{C}(15)$ & $99.20(8)$ & $\mathrm{Si}(1)-\mathrm{C}(1)-\mathrm{C}(6)-\mathrm{C}(2) \mathrm{A}$ & $162.80(10)$ \\
\hline $\mathrm{Si}(1) \cdots \operatorname{Si}(1) \mathrm{A}$ & $6.6403(6)$ & $\mathrm{C}(14)-\mathrm{Si}(1)-\mathrm{C}(15)$ & $110.73(8)$ & $C(1)-C(6)-C(10)-N(2)$ & $-40.48(16)$ \\
\hline & & & & $C(2) A-C(6)-C(10)-N(2)$ & $132.50(12)$ \\
\hline \multicolumn{6}{|c|}{ Compound $\mathbf{1 0}$} \\
\hline $\operatorname{Sn}(1)-C(1)$ & $2.178(2)$ & $C(1)-S n(1)-C(10)$ & $113.36(11)$ & $C(1)-C(2)-C(3)-C(1) A$ & $4.0(3)$ \\
\hline $\mathrm{Sn}(1)-C(10)$ & $2.171(3)$ & $C(1)-S n(1)-C(11)$ & $120.51(9)$ & $C(2)-C(1)-C(3) A-C(2) A$ & $3.9(3)$ \\
\hline$S n(1)-C(11)$ & $2.139(3)$ & $C(1)-S n(1)-C(12)$ & 107.27(9) & $C(3) A-C(1)-C(2)-C(3)$ & $-3.9(3)$ \\
\hline $\mathrm{Sn}(1)-C(12)$ & $2.176(3)$ & $C(10)-S n(1)-C(11)$ & 108.45(13) & $S n(1)-C(1)-C(2)-C(3)$ & 168.11(16) \\
\hline $\mathrm{Sn}(1)-N(1)$ & $2.857(2)$ & $C(10)-S n(1)-C(12)$ & 94.85(11) & $S n(1)-C(1)-C(3) A-C(2) A$ & $-168.05(16)$ \\
\hline$S n(1)-N(2) A$ & $2.999(2)$ & $C(11)-S n(1)-C(12)$ & $109.28(11)$ & $C(1)-C(2)-C(4)-N(1)$ & $-33.7(3)$ \\
\hline $\operatorname{Sn}(1) \cdots \operatorname{Sn}(1) A$ & $7.1659(11)$ & $N(1)-S n(1)-N(2) A$ & $107.07(5)$ & $C(3)-C(2)-C(4)-N(1)$ & $142.6(2)$ \\
\hline & & & & $C(1) A-C(3)-C(5)-N(2)$ & $-39.4(3)$ \\
\hline & & & & $C(2)-C(3)-C(5)-N(2)$ & $134.9(2)$ \\
\hline \multicolumn{6}{|c|}{ Compound $\mathbf{1 8} \mathbf{b}^{d}$} \\
\hline cationic fragment & & & & & \\
\hline$S n(1)-C(1)$ & $2.105(2)$ & $C(1)-S n(1)-C(10)$ & $123.43(10)$ & $C(1)-C(2)-C(3)-C(1) A$ & $0.0(9)$ \\
\hline $\mathrm{Sn}(1)-C(10)$ & $2.116(2)$ & $C(1)-S n(1)-C(11)$ & $120.81(10)$ & $C(2)-C(1)-C(3) A-C(2) A$ & $0.0(15)$ \\
\hline $\mathrm{Sn}(1)-C(11)$ & $2.111(2)$ & $C(10)-S n(1)-C(11)$ & 115.76(11) & $C(3) A-C(1)-C(2)-C(3)$ & $0.0(15)$ \\
\hline $\operatorname{Sn}(1)-N(1)$ & $2.395(2)$ & $N(1)-S n(1)-N(2) A$ & $152.05(7)$ & $S n(1)-C(1)-C(2)-C(3)$ & $-177.07(17)$ \\
\hline$S n(1)-N(2) A$ & $2.392(2)$ & & & $S n(1)-C(1)-C(3) A-C(2) A$ & $177.10(17)$ \\
\hline $\operatorname{Sn}(1) \cdots \operatorname{Sn}(1) A$ & $6.9281(10)$ & & & $C(1)-C(2)-C(4)-N(1)$ & $-29.7(3)$ \\
\hline & & & & $C(3)-C(2)-C(4)-N(1)$ & $153.2(2)$ \\
\hline & & & & $\mathrm{C}(1) \mathrm{A}-\mathrm{C}(3)-\mathrm{C}(5)-\mathrm{N}(2)$ & $27.2(3)$ \\
\hline & & & & $\mathrm{C}(2)-\mathrm{C}(3)-\mathrm{C}(5)-\mathrm{N}(2)$ & $-156.7(2)$ \\
\hline \multicolumn{6}{|l|}{ anionic fragment } \\
\hline $\mathrm{Sn}(2)-\mathrm{C}(12)$ & $2.126(3)$ & $C(12)-S n(2)-C(13)$ & $117.75(13)$ & & \\
\hline$S n(2)-C(13)$ & $2.119(2)$ & $C(12)-S n(2)-C(14)$ & $121.40(13)$ & & \\
\hline $\operatorname{Sn}(2)-C(14)$ & $2.120(3)$ & $C(13)-S n(2)-C(14)$ & $120.84(11)$ & & \\
\hline $\mathrm{Sn}(2)-\mathrm{Cl}(1)$ & $2.6557(9)$ & $\mathrm{Cl}(1)-\mathrm{Sn}(2)-\mathrm{Cl}(2)$ & $178.27(2)$ & & \\
\hline $\mathrm{Sn}(2)-\mathrm{Cl}(2)$ & $2.5906(9)$ & & & & \\
\hline
\end{tabular}

alternative improved synthesis of solvent-free 4 that involves the reaction of $\mathrm{C}_{6} \mathrm{H}_{4}\left(\mathrm{CH}_{2} \mathrm{NMe}_{2}\right)_{2}-1,3$ with n$\mathrm{BuLi}$ in an alkane solvent. Although the structure of 4 in the solid state is unknown, in solution it is dimeric, 11a with the $\mathrm{C}_{\text {ipso }}$ carbon atom of the aryl nucleus bridging the two lithium atoms $\left({ }^{1} \mathrm{~J}\left({ }^{6} \mathrm{Li},{ }^{13} \mathrm{C}\right)=20.5 \mathrm{~Hz}\right)^{11 \mathrm{~b}}$ and with each lithium atom intramolecularly coordinated by two $\mathrm{CH}_{2} \mathrm{NMe}_{2}$ substituents. Furthermore, it is known from NMR spectroscopic and X-ray crystallographic studies that the analogous p-phenyl-substituted derivative of 4, $\left[\mathrm{Li}\left\{\mathrm{C}_{6} \mathrm{H}_{2}\left(\mathrm{CH}_{2} \mathrm{NMe}_{2}\right)_{2}-2,6-\mathrm{C}_{6} \mathrm{H}_{5}-4\right\}\right]_{2},{ }^{11 \mathrm{c}}$ and the related monolithium species 7, $\left[\mathrm{Li}\left\{\mathrm{C}_{6} \mathrm{H}\left(\mathrm{CH}_{2} \mathrm{NMe}_{2}\right)_{4}-2,3,5,6\right\}\right]_{2},{ }^{10}$ are dimeric both in solution and in the sol id state. Also the X-ray crystallographic analysis of the $\mathrm{NEt}_{2}$ analog of 4, i.e., $\left[\mathrm{Li}\left\{\mathrm{C}_{6} \mathrm{H}_{3}\left(\mathrm{CH}_{2} \mathrm{NEt}_{2}\right)_{2}-2,6\right\}\right]_{2}$, recently reported by Schlengermann et al., 11d supports a dimeric solid state structure of $\mathbf{4}$.

We are currently investigating in detail both the solution and solid-state geometries of the new organodilithium reagent $\left[\mathrm{Li}_{2}-1,4-\left\{\mathrm{C}_{6}\left(\mathrm{CH}_{2} \mathrm{NMe}_{2}\right)_{4}-2,3,5,6\right\}\right]_{\infty}$ (3). Based on its insolubility when prepared in $\mathrm{Et}_{2} \mathrm{O}$, we propose that it has a highly aggregated (polymeric) structure in the solid state as illustrated schematically in Figure 5. In this form, complex $\mathbf{3}$ is insol uble in THF. However, when prepared in THF, 3 remains dissolved and in this situation it is probably present as a less aggregated dilithium species of $\mathrm{C}_{2} \mathrm{~N}_{4}$ (probably monomeric or dimeric) as a result of coordination of THF to the lithium centers and involvement of lithium halide generated during the lithiation reaction.
The new organodilithium compound $\mathbf{3}$ is an interesting synthetic reagent with which we have successfully prepared 1,4-phenylene-bridged dinuclear organometallic complexes of the group 14 metals silicon and tin (this paper) and of some platinum group metals. ${ }^{8 b}$

Unusual Geometries and Reactivity. Tetraorganosilicon and -tin compounds were long regarded as being unable to extend their coordination number due to the poor acceptor properties of the metal center in such species. ${ }^{4 c}$ However, many examples have now been reported in which the silicon or tin centers may be regarded as hypercoordinate, as a result of additional intramol ecular coordination. ${ }^{3-5}$ In this paper, we have shown that both in the solid state (X-ray crystallographic studies) and in solution (NMR spectroscopic data) the ligands $\mathrm{NCN}$ and $\mathrm{C}_{2} \mathrm{~N}_{4}$ are able to empl oy the $\mathrm{CH}_{2} \mathrm{NMe}_{2}$ substituents for varying degrees of extra intramolecular $\mathrm{N}$-donor coordination to the metal center. This $\mathrm{N}$-donor coordination occurs even though there are no electronegative groups on the group 14 metal centers in these silanes and stannanes. The resulting silanes $\mathbf{5}$ and $\mathbf{9}$ and stannanes $\mathbf{6}$ and $\mathbf{1 0}$ are air-stable colorless materials that have physical properties similar to those of unsubstituted phenyl and 1,4-phenylene (bis)silanes and (bis)stannanes.

In contrast to their physical properties, the chemical properties of the new $\mathrm{NCN}$ and $\mathrm{C}_{2} \mathrm{~N}_{4}$ organometallic complexes of $\mathrm{Si}$ and $\mathrm{Sn}$ are different from those of the corresponding "free" silanes and stannanes (e.g., $\left[\mathrm{C}_{6} \mathrm{H}_{5}\right.$ $\left.\mathrm{MMe}_{3}\right]$ and $\left[\left(\mathrm{Me}_{3} \mathrm{M}\right)_{2}-1,4-\mathrm{C}_{6} \mathrm{H}_{4}\right]$, with $\left.\mathrm{M}=\mathrm{Si}, \mathrm{Sn}\right)$. The 
Table 4. Crystallographic data for 9,10 , and $18 b$

\begin{tabular}{|c|c|c|c|}
\hline compound & 9 & 10 & $18 b$ \\
\hline \multicolumn{4}{|c|}{ Crystal Data } \\
\hline $\begin{array}{l}\text { formula } \\
\text { mol wt }\end{array}$ & $\begin{array}{l}\mathrm{C}_{24} \mathrm{H}_{50} \mathrm{~N}_{4} \mathrm{Si}_{2} \\
450.86\end{array}$ & $\begin{array}{l}\mathrm{C}_{24} \mathrm{H}_{50} \mathrm{~N}_{4} \mathrm{Sn}_{2} \\
632.11\end{array}$ & $\begin{array}{l}{\left[\mathrm{C}_{22} \mathrm{H}_{44} \mathrm{~N}_{4} \mathrm{Sn}_{2}\right]\left[\mathrm{C}_{3} \mathrm{H}_{9} \mathrm{SnCl}_{2}\right]_{2}} \\
1071.48\end{array}$ \\
\hline cryst syst & triclinic & monoclinic & monodinic \\
\hline space group & $\mathrm{P} \overline{1}($ No. 2$)$ & $\mathrm{P} 2_{1} / \mathrm{C}($ No. 14$)$ & $\mathrm{P} 2_{1} / \mathrm{C}$ (No. 14) \\
\hline$a, \AA$ & $8.4391(5)$ & $9.7564(9)$ & $14.8868(10)$ \\
\hline $\mathrm{b}, \AA$ & $9.6587(6)$ & $12.8044(12)$ & $7.5203(10)$ \\
\hline$c, \AA$ & $9.9458(6)$ & $12.856(2)$ & $21.441(3)$ \\
\hline$\alpha$, deg & $71.049(6)$ & & \\
\hline$\beta$, deg & $83.138(5)$ & $117.181(9)$ & $121.317(6)$ \\
\hline$\gamma$, deg & $64.767(5)$ & & \\
\hline$V, \AA^{3}$ & $693.42(9)$ & $1428.7(3)$ & $2050.7(4)$ \\
\hline $\mathrm{D}_{\text {calc }}, \mathrm{g} \mathrm{cm}^{-3}$ & 1.080 & 1.469 & 1.735 \\
\hline & 1 & & 2 \\
\hline$F(000)$ & 250 & 644 & 1052 \\
\hline$\mu[\mathrm{M} \circ \mathrm{K} \alpha], \mathrm{cm}^{-1}$ & 1.5 & 17.6 & 26.9 \\
\hline cryst size, mm & $0.25 \times 0.38 \times 0.50$ & $0.25 \times 0.40 \times 0.40$ & $0.2 \times 0.4 \times 0.6$ \\
\hline \multicolumn{4}{|c|}{ Data Collection } \\
\hline $\begin{array}{l}\theta_{\min }, \theta_{\max }, \text { deg } \\
\text { SET4 } \theta_{\min }, \theta_{\text {max }} \text {, deg }\end{array}$ & $\begin{array}{l}2.2,27.5 \\
10.27,13.69\end{array}$ & $\begin{array}{l}1.6,27.5 \\
9.90,14.09\end{array}$ & $\begin{array}{l}1.1,27.5 \\
11.46,14.03\end{array}$ \\
\hline scan type & $\omega / 2 \theta$ & $\omega$ & $\omega$ \\
\hline$\Delta \omega$, deg & $0.59+0.35 \tan \theta$ & $0.59+0.35 \tan \theta$ & $0.71+0.35 \tan \theta$ \\
\hline Hor, vert aperture, $\mathrm{mm}$ & $3.00,4.00$ & $2.52+1.26 \tan \theta, 4.00$ & $2.60+1.30 \tan \theta, 4.00$ \\
\hline $\mathrm{X}$-ray exposure time, $\mathrm{h}$ & 22 & 16 & 29 \\
\hline linear instability, \% & & 2 & 7 \\
\hline ref reflctns & $250,-4-2-2,34-2$ & $-252,-32-2,-133$ & $02-5,23-5,12-3$ \\
\hline data set & $-10: 10,-12: 12,-10: 10$ & $-12: 12,-16: 0,-16: 16$ & $-12: 19,-9: 9,-27: 23$ \\
\hline total no. of data & 6700 & 7253 & 10316 \\
\hline $\begin{array}{l}\text { total no. of unique data } \\
\text { DIFABS cor range }\end{array}$ & $3166\left(R_{\text {int }}=0.0369\right)$ & $3279\left(R_{\text {int }}=0.0485\right)$ & $\begin{array}{l}4699\left(R_{\text {int }}=0.0240\right) \\
0.702,1.771\end{array}$ \\
\hline \multicolumn{4}{|c|}{ Refinement } \\
\hline no. of refined params & 143 & 211 & 201 \\
\hline final $R^{a}$ & $0.0327[2779 \mid>2 \sigma(I)]$ & $0.0225[2741 \mid>2 \sigma(I)]$ & $0.0214[4224 \mathrm{I}>2 \sigma(\mathrm{I})]$ \\
\hline final $w R 2^{b}$ & 0.0878 & 0.0485 & 0.0509 \\
\hline goodness of fit & $\begin{array}{l}1.089 \\
g^{2}\left(\mathrm{~F}^{2}\right)+(0.0318 \mathrm{P})^{2}+021 \mathrm{P}\end{array}$ & $\begin{array}{l}1.059 \\
\sigma^{2}\left(\mathrm{~F}^{2}\right)+(0.0196\end{array}$ & $\begin{array}{l}1.082 \\
\sigma^{2}\left(\mathrm{~F}^{2}\right)+(0.0260 \mathrm{P})^{2}+0.55 \mathrm{P}\end{array}$ \\
\hline $\begin{array}{l}\mathrm{W}^{-1 \mathrm{c}} \\
(\Delta / \sigma)_{\mathrm{av}},(\Delta / \sigma)_{\max }\end{array}$ & $\begin{array}{l}\sigma^{2}\left(\mathrm{r}^{2}\right)+(0.0318 \mathrm{P})^{2}+0.21 \mathrm{P} \\
0.000,0.000\end{array}$ & $\begin{array}{l}\sigma^{2}\left(\mathrm{~F}^{2}\right)+(0.019 \\
0.000,0.009\end{array}$ & $\begin{array}{l}\sigma^{2}\left(\mathrm{~F}^{2}\right)+(0.0260 \mathrm{P})^{2}+0.55 \mathrm{P} \\
0.000,0.001\end{array}$ \\
\hline min and max resid dens, e $\AA^{-3}$ & $-0.24,0.32$ & $-0.45,0.51$ (near Sn) & $-0.84,0.46$ (near Sn) \\
\hline
\end{tabular}

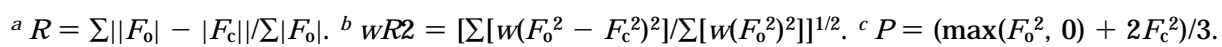

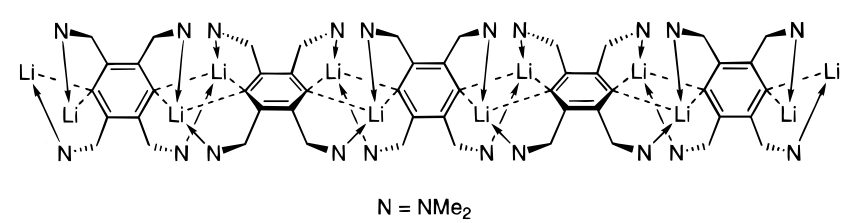

Figure 5. Schematic representation of the proposed highly aggregated (polymeric) structure of dilithiated $\mathrm{C}_{2} \mathrm{~N}_{4}$, $\mathbf{4}$, in the solid state.

intramolecularly coordinating $\mathrm{CH}_{2} \mathrm{NMe}_{2}$ groups in the silicon and tin complexes 5, 6, 9, and $\mathbf{1 0}$ cause an increase in electron density at the metal centers and the overall metal coordination geometry and disposition of the organic groups bonded to the metal center changes significantly. In particular, as illustrated in the X-ray molecular structures of $\mathbf{9}$ and $\mathbf{1 0}$, there is also a significant lengthening (i.e., probable activation) of an $\mathrm{M}-\mathrm{Me}$ bond that is positioned trans to the $\mathrm{N}$-donor atom of the coordinated $\mathrm{CH}_{2} \mathrm{NMe}_{2}$ group.

In our study, we find that the reaction of silanes $\mathbf{5}$ and 9 with $\mathrm{Pd}(\mathrm{OAc})_{2}$ results in selective electrophilic $\mathrm{C}_{\text {aryl }}-\mathrm{Si}$ bond palladation. The reason for this increased reactivity of silanes $\mathbf{5}$ and $\mathbf{9}$ can be found from the solidstate structure of bis(silane) $\mathbf{9}$, in which each silicon(IV) center becomes pentacoordinate as a result of intramolecular $\mathrm{N}$-donor coordination of one $\mathrm{CH}_{2} \mathrm{NMe}_{2}$ substituent (Figure 2). This results in higher electron density and thereby in an increased reactivity of the $\mathrm{C}_{\text {aryl }}-\mathrm{Si}$ bonds of $\mathbf{9}$ (and of $\mathbf{5}$ ). This reactivity can be applied in the synthesis of mononuclear and homodinuclear organometallic palladium(II) complexes of the ligands NCN and $\mathrm{C}_{2} \mathrm{~N}_{4}$. Moreover, experiments invol ving platinum(II) substrates show that none of the $\mathrm{C}-\mathrm{Si}$ bonds in $\mathbf{5}$ and 9 are susceptible to electrophilic platination. This difference between palladium(II) and platinum(II) substrates affords the opportunity to prepare heterobimetallic complexes, as we recently communicated, ${ }^{8 b}$ through selective introduction of the different metal centers in two separate steps.

Analogously, in attempted el ectrophilic $\mathrm{C}_{\text {aryl }}-\mathrm{Si}$ bond palladation reactions, it has been found that (3-naphthyl)trimethylsilane is almost unreactive toward $\mathrm{Pd}(\mathrm{OAC})_{2}$ or $\left[\mathrm{Li}_{2} \mathrm{PdCl}_{4}\right]$. However, the corresponding silane that has a $\mathrm{CH}_{2} \mathrm{NMe}_{2}$ substituent at the 2-position of the naphthyl group reacts readily with the same palladium(II) substrates to form a 3-cyclometalated product by a $\mathrm{C}-\mathrm{Si}$ bond cleavage reaction (F igure $6 \mathrm{a}$ ). ${ }^{24}$ In addition, introduction of a trimethylsilyl group at the 1-position of 2-[(dimethylamino)methyl ]naphthalene completely reverses the site selectivity from electrophilic palladation at the 3-position ( $\mathrm{C}-\mathrm{H}$ bond activation) to selective cyclometalation at the 1-position (C-Si bond cleavage; Figure $6 \mathrm{~b}){ }^{25}$

In this paper we have shown that the new stannanes $\mathbf{6}$ and $\mathbf{1 0}$ have reactivity patterns that are different from

(24) Valk, J .-M.; van Belzen, R.; Boersma, J .; Spek, A. L.; van Koten, G. J . Chem. Soc., Dalton Trans. 1994, 2293.

(25) Valk, J .-M.; Boersma, J .; van Koten, G. J . Organomet. Chem. 1994, 483, 213. 
a. $\mathrm{C}-\mathrm{H}$ and $\mathrm{C}-\mathrm{Si}$ bond cleavage:

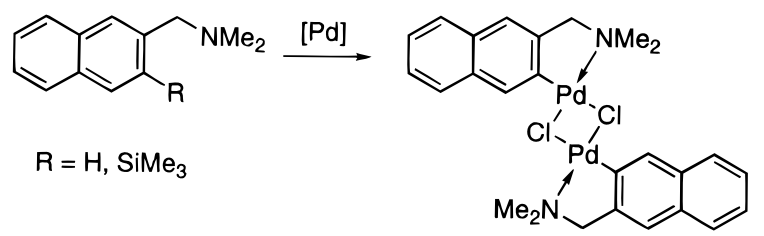

b. Selective C-Si bond cleavage:

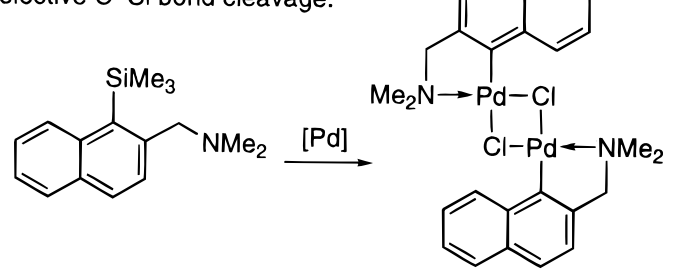

Figure 6. $\mathrm{C}-\mathrm{H}$ and $\mathrm{C}-\mathrm{Si}$ bond cleavage reactions (a) and the directional effect of a $\mathrm{Me}_{3} \mathrm{Si}$ group (b) on the site of cyclopalladation of a naphthylamine.

those encountered with tetracoordinate aryltrialkyltin compounds. The $\mathrm{C}_{\mathrm{Me}}-\mathrm{Sn}$ bond el ongation identified in the structure of $\mathbf{1 0}$ is directly translated in the reactivity of the hexacoordinate stannane $\mathbf{1 0}$ (and 6) toward palladium(II) and platinum(II) substrates. Whereas interaction of these stannanes $\mathbf{6}$ and $\mathbf{1 0}$ with platinum(II) species [ $\left.\mathrm{PtCl}_{2}(\mathrm{COD})\right]$ was seen to result in selective alkyl transfer to afford methylplatinum complex [PtCl(Me)(COD)], the corresponding interaction with palladium(II) substrates results in selective aryl transfer to afford palladium(II) complexes of $\mathrm{NCN}$ and $\mathrm{C}_{2} \mathrm{~N}_{4}$, respectively. These results with $\mathbf{6}$ and $\mathbf{1 0}$ contrast with those of the tetracoordinate aryltrialkyltin species $\mathrm{Ph}$ $\mathrm{SnMe}_{3}$, which reacts with $\left[\mathrm{M}^{\prime} \mathrm{Cl}_{2}(\mathrm{COD})\right]$, where $\mathrm{M}^{\prime}$ is either palladium or platinum, to afford in both cases via selective aryl transfer the product [M'(Ph)Cl(COD)]. ${ }^{2}$

It has been proposed that the higher reactivity of aryltrialkylstannanes bearing intramolecularly coordinating electron donor substituents relative to that of analogs without such substituents is the result of an increase in electron density at the tin(IV) center, in combination with the elongation of $\mathrm{C}_{\text {alkyl }}-\mathrm{Sn}$ bonds that are trans to a coordinated donor substituent. ${ }^{4}$ For instance, J astrzebski et al., ${ }^{4 a}$ reported that [8-(dimethylamino)-1-naphthyl]trimethylstannane reacts with $\left[\mathrm{PtCl}_{2}(\mathrm{COD})\right]$ to afford [PtCl(Me)(COD)] through a methyl-transfer reaction and [8-(dimethylamino)-1-naphthyl]dimethyltin chloride (Figure 7b). In contrast, the group of Eaborn showed that (1-naphthyl)trimethylstannane reacts with the same substrate to afford a product that is now the result of an aryl group-transfer reaction (Figure 7a), and this type of reactivity was found to be normal for the interaction of several mixed alkyl/ arylstannanes with platinum halides. ${ }^{23}$

\section{Conclusion}

In this investigation of the ligands $\left[\mathrm{C}_{6} \mathrm{H}_{3}\left(\mathrm{CH}_{2} \mathrm{NMe}_{2}\right)_{2}-\right.$ $2,6]^{-}(\mathrm{NCN})$ and $\left[\mathrm{C}_{6}\left(\mathrm{CH}_{2} \mathrm{NMe}_{2}\right)_{4}-2,3,5,6\right]^{2-}\left(\mathrm{C}_{2} \mathrm{~N}_{4}\right)$, we have found that they afford organometallic complexes of the group 14 (IVB) metals silicon and tin in which $\mathrm{N}$-donor coordination of $\mathrm{CH}_{2} \mathrm{NMe}_{2}$ substituents plays an important role in the overall coordination motif. This flexible behavior of $\mathrm{NCN}$ and $\mathrm{C}_{2} \mathrm{~N}_{4}$ results in a series of new hypercoordinate aryltrialkylsilanes and -stan- a. Selective Aryl Transfer:

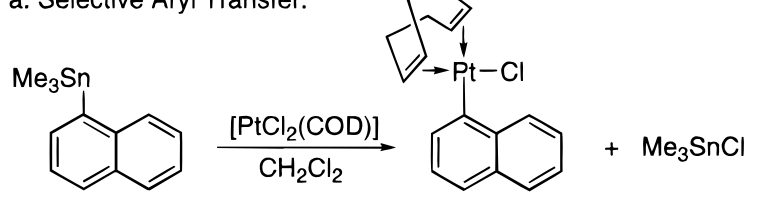

b. Selective Alkyl Transfer:

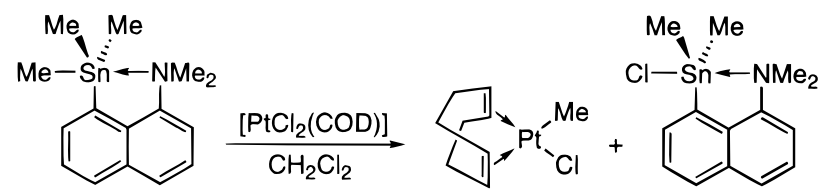

Figure 7. Selective aryl (a) vs alkyl (b) transfer to $\left[\mathrm{PtCl}_{2}-\right.$ (COD)].

nanes with interesting structural and reactivity features. In particular, arylstannanes of these ligands are more reactive toward diverse platinum group metal complexes then the corresponding arylsilanes. Moreover, the silanes and stannanes derived from $\mathrm{C}_{2} \mathrm{~N}_{4}$ are versatile reagents which provide synthetic pathways to new dinudear organometallic complexes with a 1,4phenylene bridge.

\section{Experimental Section}

General Comments. All organometallic syntheses were performed in a dry dinitrogen atmosphere, using standard Schlenk techniques. The solvents were dried and freshly distilled prior to use. ${ }^{1} \mathrm{H},{ }^{13} \mathrm{C},{ }^{29} \mathrm{Si}$, and ${ }^{119} \mathrm{~S} n \mathrm{NMR}$ measurements were performed at $298 \mathrm{~K}$ with a Bruker AC200 or AC300 spectrometer, with chemical shifts referenced to either $\mathrm{Me}_{4} \mathrm{Si}$ or $\mathrm{Me}_{4} \mathrm{Sn}$. Elemental microanalyses were carried out by Dornis und Kolbe, Mikroanalytisches Laboratorium, Mülheim, Germany. The compounds $\mathrm{C}_{6} \mathrm{H}_{2}\left(\mathrm{CH}_{2} \mathrm{Br}\right)_{4}-1,2,4,5,{ }^{26}$ [ $\mathrm{Li}$ $\left.\left\{\mathrm{C}_{6} \mathrm{H}\left(\mathrm{CH}_{2} \mathrm{NMe}_{2}\right)_{4}-2,3,5,6\right\}\right]_{2}(7),{ }^{10}$ and $\mathrm{C}_{6} \mathrm{Br}_{2}\left(\mathrm{CH}_{2} \mathrm{Br}\right)_{4}-2,3,5,6$ (1) ${ }^{27}$ were prepared according to previously described methods.

Synthesis of $\mathbf{C}_{6} \mathrm{H}_{4}\left(\mathrm{CH}_{2} \mathrm{NMe}_{2}\right)_{2}-\mathbf{1 , 3}$. To stirred formic acid $(200 \mathrm{~mL}, 5.3 \mathrm{~mol})$ at room temperature in a $1 \mathrm{~L}$ Erlenmeyer flask was added over 15 min neat $\alpha, \alpha^{\prime}$-diamino-m-xylene (32.4 $\mathrm{mL}, 0.25 \mathrm{~mol}$ ). Formaldehyde ( $200 \mathrm{~mL}$ of 37 wt \% in water, $2.65 \mathrm{~mol}$ ) was then added in one portion. The clear reaction mixture was heated, and the stirred solution was held at reflux temperature $\left(\sim 95^{\circ} \mathrm{C}\right)$ until $\mathrm{CO}_{2}$ evolution ceased $(\sim 4 \mathrm{~h})$. The mixture was cooled to $\sim 50{ }^{\circ} \mathrm{C}$ with an ice bath, and formic acid $(50 \mathrm{~mL}, 1.3 \mathrm{~mol})$ and formal dehyde $(50 \mathrm{~mL}, 0.83 \mathrm{~mol})$ were then added. The resulting clear reaction mixture was heated and kept at reflux temperature $\left(\sim 95^{\circ} \mathrm{C}\right)$ for $16 \mathrm{~h}$. The reaction mixture was cooled to room temperature with an ice bath, and concentrated aqueous $\mathrm{HCl}$ was then slowly added until a $\mathrm{pH}$ of $1-2$ was reached. The mixture was washed with $\mathrm{Et}_{2} \mathrm{O}$ (2 $\times 150 \mathrm{~mL}$ ) and then neutralised with saturated aqueous $\mathrm{NaOH}$ until a $\mathrm{pH}$ of 13-14 was reached. The product was extracted from the mixture with pentane $(3 \times 250 \mathrm{~mL})$. The combined pentane extracts were washed with saturated aqueous $\mathrm{NaCl}(200 \mathrm{~mL})$, dried with $\mathrm{K}_{2} \mathrm{CO}_{3}$, and filtered. After evaporation of the volatiles in vacuo, the product was obtained as a pale yell ow oily residue. Purification by flash distillation under reduced pressure afforded $\mathrm{C}_{6} \mathrm{H}_{4}\left(\mathrm{CH}_{2} \mathrm{NMe}_{2}\right)_{2}-1,3$ as a colorless oil. Yield: $38-42 \mathrm{~g}(80-90 \%)$. ${ }^{1} \mathrm{H}$ NMR $\left(\mathrm{CDCl}_{3}, 200\right.$ $\mathrm{MHz}): \delta 7.23(\mathrm{~m}, 4 \mathrm{H}, \mathrm{ArH}), 3.40\left(\mathrm{~s}, 4 \mathrm{H}, \mathrm{CH}_{2} \mathrm{~N}\right), 2.22(\mathrm{~s}, 12$ $\left.\mathrm{H}, \mathrm{NMe}_{2}\right) .{ }^{1 \mathrm{H}} \mathrm{NMR}\left(\mathrm{C}_{6} \mathrm{D}_{6}, 200 \mathrm{MHz}\right): \delta 7.50(\mathrm{~s}, 1 \mathrm{H}, \mathrm{ArH})$, $7.21(\mathrm{~m}, 3 \mathrm{H}, \mathrm{ArH}), 3.30\left(\mathrm{~s}, 4 \mathrm{H}, \mathrm{CH}_{2} \mathrm{~N}\right), 2.10\left(\mathrm{~s}, 12 \mathrm{H}, \mathrm{NMe}_{2}\right)$. ${ }^{13} \mathrm{C} \mathrm{NMR}\left(\mathrm{CDCl}_{3}, 50 \mathrm{MHz}\right): \delta$ 138.7, 129.8, 128.1, 127.8 (Ar), $64.3\left(\mathrm{CH}_{2} \mathrm{~N}\right), 45.4\left(\mathrm{NMe}_{2}\right) .{ }^{13} \mathrm{C} \mathrm{NMR}\left(\mathrm{C}_{6} \mathrm{D}_{6}, 50 \mathrm{MHz}\right): \delta 139.9$, 129.7, 128.3, $127.8(\mathrm{Ar}), 64.6\left(\mathrm{CH}_{2} \mathrm{~N}\right), 45.5\left(\mathrm{NMe}_{2}\right)$.

(26) Ried, W.; Bodem, H. Chem. Ber. 1956, 89, 2328.

(27) Hopff, H.; Doswald, P.; Manukian, B. K. Helv. Chim. Acta 1961, $44,1231$. 
Synthesis of $\mathrm{C}_{6} \mathrm{H}_{2}\left(\mathrm{CH}_{2} \mathrm{NMe}_{2}\right)_{4}-\mathbf{1 , 2 , 4 , 5}$. A modification of a literature procedure was used. ${ }^{10}$ Solid 1,2,4,5-tetrakis(bromomethyl)benzene $(31.7 \mathrm{~g}, 70.5 \mathrm{mmol}$ ) was added to a stirred solution of dimethylamine $(63.5 \mathrm{~g}, 1.41 \mathrm{~mol})$ in $\mathrm{Et}_{2} \mathrm{O}$ $(500 \mathrm{~mL})$ at $-10^{\circ} \mathrm{C}$, and the reaction mixture then allowed to warm slowly ( $1 \mathrm{~h}$ ) to room temperature. The mixture was stirred for an additional $2 \mathrm{~h}$ at room temperature, and during this time a white suspension formed. Addition of an aqueous solution of $\mathrm{NaOH}(150 \mathrm{~mL}, 2 \mathrm{M})$ to the reaction mixture afforded a two-layer system. The organic layer was collected and the water layer extracted with $\mathrm{Et}_{2} \mathrm{O}(2 \times 250 \mathrm{~mL})$. The combined organic extracts were washed with saturated aque ous $\mathrm{NaCl}(250 \mathrm{~mL})$, dried with $\mathrm{K}_{2} \mathrm{CO}_{3}$, and evaporated in vacuo to afford the desired product as a white solid. Yield: $8.2 \mathrm{~g}$

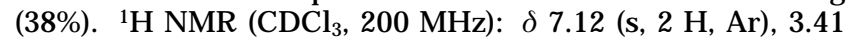
$\left(\mathrm{s}, 8 \mathrm{H}, \mathrm{CH}_{2} \mathrm{~N}\right), 2.14\left(\mathrm{~s}, 24 \mathrm{H}, \mathrm{NMe}_{2}\right)$. ${ }^{1} \mathrm{H} N M R\left(\mathrm{C}_{6} \mathrm{D}_{6}, 200\right.$ $\mathrm{MHz}): \delta 7.49(\mathrm{~s}, 2 \mathrm{H}, \mathrm{Ar}), 3.59\left(\mathrm{~s}, 8 \mathrm{H}, \mathrm{CH}_{2} \mathrm{~N}\right), 2.15(\mathrm{~s}, 24 \mathrm{H}$, $\left.\mathrm{NMe}_{2}\right) .{ }^{13} \mathrm{C} \mathrm{NMR}\left(\mathrm{CDCl}_{3}, 50 \mathrm{MHz}\right): \delta 136.3,132.4(\mathrm{Ar}), 61.0$ $\left(\mathrm{CH}_{2} \mathrm{~N}\right), 45.5\left(\mathrm{NMe}_{2}\right) .{ }^{13} \mathrm{C} N M R\left(\mathrm{C}_{6} \mathrm{D}_{6}, 50 \mathrm{MHz}\right): \delta 137.1,132.7$ (Ar), $61.7\left(\mathrm{CH}_{2} \mathrm{~N}\right), 45.7\left(\mathrm{NMe}_{2}\right)$.

Synthesis of $\mathbf{C}_{6} \mathbf{B r}_{\mathbf{2}}\left(\mathrm{CH}_{2} \mathrm{NMe}_{2}\right)_{\mathbf{4}}-\mathbf{2 , 3 , 5 , 6}$ (2). Neat $\mathrm{HNMe}_{2}$ ( $22 \mathrm{~mL}, 330 \mathrm{mmol}$ ) was added to a white suspension of $\mathbf{1}$ (15 $\mathrm{g}, 24.7 \mathrm{mmol})$ in $\operatorname{THF}(150 \mathrm{~mL})$ at $-10{ }^{\circ} \mathrm{C}$. The reaction mixture was allowed to warm to room temperature over a period of $1 \mathrm{~h}$ and then heated to $55^{\circ} \mathrm{C}$ for $5 \mathrm{~min}$. The reaction mixture was allowed to cool to room temperature, and all volatiles were removed in vacuo to leave a white solid residue. This residue was suspended in aqueous $\mathrm{NaOH}(150 \mathrm{~mL}, 2 \mathrm{M})$ and with vigorous stirring of the mixture $\mathrm{Et}_{2} \mathrm{O}(500 \mathrm{~mL})$ was added. Stirring was stopped, and from the resulting two-layer system the organic layer was collected and the water layer extracted with $\mathrm{Et}_{2} \mathrm{O}(200 \mathrm{~mL})$. The combined organic layer and extracts were washed with saturated aqueous $\mathrm{NaCl}$ (100 $\mathrm{mL}$ ), dried with $\mathrm{MgSO}_{4}$ and evaporated in vacuo, to afford 2 as a white solid, which was pure enough for further synthesis. Yield: $10.7 \mathrm{~g}$ (93\%). Analytically pure colorless crystals of $\mathbf{2}$ could be obtained by slowly cooling a $\mathrm{Et}_{2} \mathrm{O}$ solution of $\mathbf{2}$ to -25 ${ }^{\circ} \mathrm{C}$. Mp: $149-152^{\circ} \mathrm{C} .{ }^{1} \mathrm{H}$ NMR $\left(\mathrm{CDCl}_{3}, 200 \mathrm{MHz}\right): \delta 3.97(\mathrm{~s}$, $\left.8 \mathrm{H}, \mathrm{CH}_{2} \mathrm{~N}\right), 2.27\left(\mathrm{~s}, 24 \mathrm{H}, \mathrm{NMe}_{2}\right) .{ }^{13} \mathrm{C} \mathrm{NMR}\left(\mathrm{CDCl}_{3}, 50 \mathrm{MHz}\right)$; $\delta$ 139.4, $131.9(\mathrm{Ar}), 59.7\left(\mathrm{CH}_{2} \mathrm{~N}\right), 45.4\left(\mathrm{NMe}_{2}\right)$. Anal. Calcd for $\mathrm{C}_{18} \mathrm{H}_{32} \mathrm{Br}_{2} \mathrm{~N}_{4}$ : C, 46.56; $\mathrm{H}, 6.95 ; \mathrm{N}, 12.07$. Found: $\mathrm{C}, 46.63$; $\mathrm{H}, 6.93 ; \mathrm{N}, 12.15$.

Synthesis of $\left[\mathrm{Li}\left\{\mathrm{C}_{6} \mathrm{H}_{\mathbf{3}}\left(\mathrm{CH}_{\mathbf{2}} \mathrm{NMe}_{2}\right)_{\mathbf{2}}-\mathbf{2 , 6}\right\}\right]_{\mathbf{2}}$ (4). n-BuLi (20 $\mathrm{mL}, 1.6 \mathrm{M}$ in hexanes, $32 \mathrm{mmol}$ ) was added dropwise (5 min) to a stirred solution of $\mathrm{C}_{6} \mathrm{H}_{4}\left(\mathrm{CH}_{2} \mathrm{NMe}_{2}\right)_{2}-1,3(6.12 \mathrm{~g}, 31.8 \mathrm{mmol})$ in hexane $(100 \mathrm{~mL})$ at room temperature. The reaction mixture was then stirred for $18 \mathrm{~h}$ at room temperature. The reaction mixture was then evaporated to dryness, to afford 4 quantitatively as an off-white solid, sufficiently pure for further syntheses. Pure microcrystalline $\mathbf{4}$ could be obtained by cooling a concentrated solution of $\mathbf{4}$ in $\mathrm{Et}_{2} \mathrm{O}$ to $-25^{\circ} \mathrm{C}$. The white solid product was collected by filtration and dried in vacuo. Yield: $4.5-5.0 \mathrm{~g}(70-80 \%)$. $\mathrm{Mp}: 80-83^{\circ} \mathrm{C}$. ${ }^{1} \mathrm{H} N M R$ $\left(\mathrm{C}_{6} \mathrm{D}_{6}, 200 \mathrm{MHz}\right): \delta 7.23\left(\mathrm{dd}, 1 \mathrm{H},{ }^{3} \mathrm{HH}_{\mathrm{HH}}=8.0\right.$ and $\left.6.3 \mathrm{~Hz}, \mathrm{ArH}\right)$, $7.21\left(\mathrm{~d}, 1 \mathrm{H}, 3 \mathrm{H}_{\mathrm{HH}}=6.3 \mathrm{~Hz}, \mathrm{ArH}\right), 7.08(\mathrm{~d}, 1 \mathrm{H}, 3.52(\mathrm{~s}, 4 \mathrm{H}$, $\mathrm{CH}_{2} \mathrm{~N}$ ), $2.14\left(\mathrm{~s}, 12 \mathrm{H}, \mathrm{NMe}_{2}\right), 0.38\left(\mathrm{~s}, 9 \mathrm{H}, \mathrm{SiMe}_{3}\right) .{ }^{13} \mathrm{C} \mathrm{NMR}$ $\left(\mathrm{C}_{6} \mathrm{D}_{6}, 50 \mathrm{MHz}\right): \delta 188.4$ (br m, $\left.\mathrm{C}_{\text {ipso }}\right), 151.8,124.4,123.6(\mathrm{Ar})$, $72.7\left(\mathrm{CH}_{2} \mathrm{~N}\right), 45.3\left(\mathrm{NMe}_{2}\right)$.

Synthesis of $\left[\mathrm{Me}_{3} \mathrm{Si}\left\{\mathrm{C}_{6} \mathrm{H}_{3}\left(\mathrm{CH}_{2} \mathrm{NMe}_{2}\right)_{2}-2,6\right\}\right]$ (5). A solution of (trimethylsilyl)trifluoromethanesulfonate $(5.7 \mathrm{~mL}, 29.3$ $\mathrm{mmol}$ ) in THF ( $20 \mathrm{~mL}$ ) was added over a period of $5 \mathrm{~min}$ to a stirred solution of 1,3-bis[(dimethylamino)methyl]phenyllithium $(4 ; 5.29 \mathrm{~g}, 13.4 \mathrm{mmol})$ in hexane $(80 \mathrm{~mL})$ at room temperature, and stirring was continued at this temperature for $15 \mathrm{~min}$. The volatiles were then evaporated in vacuo, and the yellow oily residue was extracted with hexane $(2 \times 100$ $\mathrm{mL}$ ). The combined hexane extracts were evaporated in vacuo, and the resulting dark yellow oil was purified by flash distillation under reduced pressure, to afford pure $\mathbf{5}$ as a

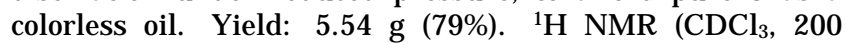
$\mathrm{MHz}): \delta 7.26(\mathrm{~m}, 3 \mathrm{H}, \mathrm{ArH}), 3.52\left(\mathrm{~s}, 4 \mathrm{H}, \mathrm{CH}_{2} \mathrm{~N}\right), 2.14(\mathrm{~s}, 12$ $\left.\mathrm{H}, \mathrm{NMe}_{2}\right), 0.38\left(\mathrm{~s}, 9 \mathrm{H}, \mathrm{SiMe}_{3}\right) .{ }^{13} \mathrm{CNMR}\left(\mathrm{CDCl}_{3}, 50 \mathrm{MHz}\right): \delta$
146.4, 138.6, $128.4(\mathrm{Ar}), 64.9\left(\mathrm{CH}_{2} \mathrm{~N}\right), 45.3\left(\mathrm{NMe}_{2}\right), 3.3\left(\mathrm{SiMe}_{3}\right)$. ${ }^{29} \mathrm{Si} \mathrm{NMR}\left(\mathrm{C}_{6} \mathrm{D}_{6}, 59.6 \mathrm{MHz}\right): \delta-7.7\left(\mathrm{SiMe}_{3}\right)$. Anal. Calcd for $\mathrm{C}_{15} \mathrm{H}_{28} \mathrm{~N}_{2} \mathrm{Si}$ : C, $68.12 ; \mathrm{H}, 10.67 ; \mathrm{N}, 10.59$. Found: C, 68.25; $\mathrm{H}, 10.74 ; \mathrm{N}, 10.51$.

Synthesis of $\left[\mathrm{Me}_{3} \mathrm{Sn}\left\{\mathrm{C}_{6} \mathrm{H}_{3}\left(\mathrm{CH}_{2} \mathrm{NMe}_{2}\right)_{2}-2,6\right\}\right]$ (6). A solution of $\mathrm{Me} \mathrm{SnCl}_{3}(2.10 \mathrm{~g}, 10.6 \mathrm{mmol})$ in $\mathrm{Et}_{2} \mathrm{O}(10 \mathrm{~mL})$ was added dropwise over a period of $5 \mathrm{~min}$ to a stirred solution of $\mathbf{4}$ (2.06 $\mathrm{g}, 5.2 \mathrm{mmol})$ in $\mathrm{Et}_{2} \mathrm{O}(20 \mathrm{~mL})$ at room temperature, and stirring of the reaction mixture was continued for $2 \mathrm{~h}$. After this time, the reaction mixture was evaporated to dryness in vacuo, to afford a yellow oily residue. This material was diluted with hexane $(50 \mathrm{~mL})$ and filtered to remove $\mathrm{LiCl}$. The filtrate was evaporated in vacuo to leave crude $\mathbf{6}$ as a yellow oil. Purification by flash distillation under reduced pressure afforded stannane $\mathbf{6}$ as a colorless oil which slowly solidified at room temperature. Yield: $3.37 \mathrm{~g}(92 \%)$. Mp: $37-39^{\circ} \mathrm{C}$. ${ }^{1} \mathrm{H}$ NMR $\left(\mathrm{C}_{6} \mathrm{D}_{6}, 200 \mathrm{MHz}, 298 \mathrm{~K}\right): \delta 7.00(\mathrm{~m}, 3 \mathrm{H}, \mathrm{ArH}), 3.34(\mathrm{~s}, 4 \mathrm{H}$, $\left.\mathrm{CH}_{2} \mathrm{~N}\right), 1.92\left(\mathrm{~s}, 12 \mathrm{H}, \mathrm{NMe}_{2}\right), 0.30\left(\mathrm{~s}, 9 \mathrm{H},{ }^{2} \mathrm{~J} \mathrm{snH}=53 \mathrm{~Hz}\right.$ and $\left.51 \mathrm{~Hz}, \mathrm{Me}_{3} \mathrm{Sn}\right)$. ${ }^{1} \mathrm{H} \mathrm{NMR}\left(\mathrm{CDCl}_{3}, 200 \mathrm{MHz}\right): \delta 7.25(\mathrm{~m}, 3 \mathrm{H}$, $\mathrm{ArH}), 3.63\left(\mathrm{~s}, 4 \mathrm{H}, \mathrm{CH}_{2} \mathrm{~N}\right), 2.22\left(\mathrm{~s}, 12 \mathrm{H}, \mathrm{NMe}_{2}\right), 0.37(\mathrm{~s}, 9 \mathrm{H}$, ${ }^{2} \mathrm{~J} \mathrm{SnH}=53 \mathrm{~Hz}$ and $\left.51 \mathrm{~Hz}, \mathrm{Me}_{3} \mathrm{Sn}\right) .{ }^{13} \mathrm{C} \mathrm{NMR}\left(\mathrm{CDCl}_{3}, 50 \mathrm{MHz}\right)$; $\delta 147.4$ ( ( ) $\mathrm{Snc}=27 \mathrm{~Hz}, \mathrm{Ar}), 143.8(\mathrm{l} \mathrm{Snc}=555$ and $530 \mathrm{~Hz}$, $\mathrm{C}_{\text {ipso }}$ ), 128.3 ( $\mathrm{n} \mathrm{J} \mathrm{Snc}=45 \mathrm{~Hz}, \mathrm{Ar}$ ), 127.8 ( $\mathrm{n} \mathrm{J} \mathrm{Snc}=10 \mathrm{~Hz}, \mathrm{Ar}$ ), 66.1 ( $\left.3 \mathrm{~J} \mathrm{snc}=21 \mathrm{~Hz}, \mathrm{CH}_{2}\right), 44.9\left(\mathrm{NMe}_{2}\right),-3.4\left({ }^{1} \mathrm{~J} \mathrm{SnC}=371\right.$ and $\left.355 \mathrm{~Hz}, \mathrm{Me}_{3} \mathrm{Sn}\right)$. ${ }^{119} \mathrm{Sn} \mathrm{NMR}\left(\mathrm{C}_{6} \mathrm{D}_{6}, 75 \mathrm{MHz}\right): \delta-86.9$ (Mes $\left.\mathrm{Sn}\right)$. Anal. Calcd for $\mathrm{C}_{15} \mathrm{H}_{28} \mathrm{~N}_{2} \mathrm{Sn}$ : C, 50.74; $\mathrm{H}, 7.95 ; \mathrm{N}, 7.89$. Found: C, 50.72; H, 7.84; N, 7.83\%.

Synthesis of $\left[\left(\mathrm{Me}_{3} \mathrm{Si}\right)_{2}-1,4-\left\{\mathrm{C}_{6}\left(\mathrm{CH}_{2} \mathrm{NMe}_{2}\right)_{4}-2,3,5,6\right\}\right]$ (9). Method A. n-BuLi ( $3.1 \mathrm{~mL}, 1.6 \mathrm{M}$ solution in hexane, $5 \mathrm{mmol}$ ) was slowly added over $5 \mathrm{~min}$ to a white suspension of $\mathrm{C}_{6} \mathrm{Br}_{2^{-}}$ 1,4-( $\left.\mathrm{CH}_{2} \mathrm{NMe}_{2}\right)_{4}-2,3,5,6(2 ; 0.92 \mathrm{~g}, 2 \mathrm{mmol})$ in $\mathrm{Et}_{2} \mathrm{O}(15 \mathrm{~mL})$ at $-78{ }^{\circ} \mathrm{C}$. The reaction mixture was allowed to slowly warm to room temperature over a period of $1 \mathrm{~h}$ and then stirred for an additional $30 \mathrm{~min}$ at this temperature; during this latter period a white precipitate formed. The reaction mixture was centrifuged and the supernatant discarded. To the white solid residue suspended in THF $(20 \mathrm{~mL})$ was added neat $\mathrm{Me}_{3} \mathrm{SiOTf}$ $(1.0 \mathrm{~g}, 5 \mathrm{mmol})$ dropwise over a period of $5 \mathrm{~min}$, and the resulting reaction mixture was then stirred at room temperature for $2 \mathrm{~h}$. After this time, a clear yellow solution had formed, and the volatiles were then removed in vacuo to afford a yellow solid. This material was extracted with $\mathrm{Et}_{2} \mathrm{O}(5 \times$ $25 \mathrm{~mL}$ ). The combined ether extracts were concentrated to $\sim 50 \mathrm{~mL}$ and left at $-25^{\circ} \mathrm{C}$ for $16 \mathrm{~h}$ to afford 9 as a white microcrystalline solid. Yield: $0.84 \mathrm{~g}(93 \%)$. M p: $194-195^{\circ} \mathrm{C}$. Analytically pure crystals of $\mathbf{9}$ that were suitable for an X-ray analysis, were obtained by slowly cooling a saturated solution of $\mathbf{9}$ in warm benzene.

Method B. n-BuLi (11.5 mL, 1.6 M in hexanes, $18.4 \mathrm{mmol}$ ) was added dropwise over $5 \mathrm{~min}$ to a stirred solution of $\mathrm{C}_{6} \mathrm{H}_{2}\left(\mathrm{CH}_{2} \mathrm{NMe}_{2}\right)_{4}-2,3,5,6(5.29 \mathrm{~g}, 17.3 \mathrm{mmol})$ in hexane (150 $\mathrm{mL})$ at room temperature. The reaction mixture was stirred for $17 \mathrm{~h}$ at this temperature, and all volatiles were then removed in vacuo to afford a yellow oily residue. To this residue dissolved in THF $(40 \mathrm{~mL})$ at $0^{\circ} \mathrm{C}$ was added dropwise neat $\mathrm{Me}_{3} \mathrm{SiOTf}(3.6 \mathrm{~mL}, 20 \mathrm{mmol})$ over $5 \mathrm{~min}$. This reaction mixture was allowed to warm to room temperature and stirred for $15 \mathrm{~min}$ at this temperature. The volatiles were then removed in vacuo, and the oily residue that was obtained was treated with a mixture of $\mathrm{Et}_{2} \mathrm{O}(100 \mathrm{~mL})$ and aqueous $\mathrm{HCl}(100$ $\mathrm{mL}, 0.5 \mathrm{M}$ ) to afford a two-layer system. The water layer, containing the protonated product, was collected and washed with $\mathrm{Et}_{2} \mathrm{O}(100 \mathrm{~mL})$. This water layer was then neutralized with solid $\mathrm{NaOH}$ and the product extracted with $\mathrm{Et}_{2} \mathrm{O}(3 \times 50$ $\mathrm{mL}$ ). The combined organic extracts were dried with $\mathrm{K}_{2} \mathrm{CO}_{3}$ and evaporated in vacuo to afford a yellow oil which is mostly monosilane 8. This crude 8 was treated with n-BuLi $(11.5 \mathrm{~mL}$, 1.6 $\mathrm{M}$ in hexanes, $18.4 \mathrm{mmol}$ ) in hexane, followed by $\mathrm{Me}_{3} \mathrm{SiOTf}$ (3.6 $\mathrm{mL}, 20 \mathrm{mmol}$ ) in THF using the reaction conditions as described above. The resulting reaction mixture in THF was stirred for $15 \mathrm{~min}$ at room temperature. The vol atiles were then removed in vacuo, and the oily residue, containing 
primarily $\mathbf{8}$ and $\mathbf{9}$, was dissolved in a minimum amount of hexane and separated using column chromatography (neutral alumina). Elution with hexane: $E t_{3} \mathrm{~N}=97: 3$ gave a fraction containing 9. Evaporation of this fraction in vacuo afforded pure 9 as a white solid. Yield: $4.6 \mathrm{~g}(59 \%)$. ${ }^{1} \mathrm{H} N M R\left(\mathrm{C}_{6} \mathrm{D}_{6}\right.$, $300 \mathrm{MHz}$ ): $\delta 3.74\left(\mathrm{~s}, 8 \mathrm{H}, \mathrm{CH}_{2}\right), 2.05\left(\mathrm{~s}, 24 \mathrm{H}, \mathrm{NMe}_{2}\right), 0.46(\mathrm{~s}$, $\left.18 \mathrm{H}, \mathrm{SiMe}_{3}\right) .{ }^{13} \mathrm{C} \mathrm{NMR}\left(\mathrm{C}_{6} \mathrm{D}_{6}, 75 \mathrm{MHz}\right): \delta 144.2,143.7(\mathrm{Ar})$, $61.9\left(\mathrm{CH}_{2}\right), 44.7\left(\mathrm{NMe}_{2}\right), 4.3\left(\mathrm{SiMe}_{3}\right) .{ }^{29} \mathrm{Si} \mathrm{NMR}\left(\mathrm{C}_{6} \mathrm{D}_{6}, 59.6\right.$ $\mathrm{MHz}$ ): $\delta-11.2\left(\mathrm{SiMe}_{3}\right)$. Anal. Calcd for $\mathrm{C}_{24} \mathrm{H}_{50} \mathrm{~N}_{4} \mathrm{Si}_{2}: \mathrm{C}$, 63.93; H, 11.18; N, 12.43. Found: C, 63.77; H, 11.45; N, 12.33 .

Further elution of the column with $\mathrm{Et}_{2} \mathrm{O}: \mathrm{Et}_{3} \mathrm{~N}=97: 3$ gave a fraction containing 8, i.e., $\left[\mathrm{Me}_{3} \mathrm{Si}\left\{\mathrm{C}_{6}\left(\mathrm{CH}_{2} \mathrm{NMe}_{2}\right)_{4}-2,3,5,6\right\}\right]$. Concentration (in vacuo) of this fraction yiel ded a pale yellow oil, which solidified at room temperature. Yield: $2.4 \mathrm{~g}(36 \%)$. Mp: $38-41{ }^{\circ} \mathrm{C}$. ${ }^{1} \mathrm{H} \mathrm{NMR}\left(\mathrm{CDCl}_{3}, 200 \mathrm{MHz}\right): \delta 7.12(\mathrm{~s}, 1 \mathrm{H}$, ArH), 3.61 and $3.45\left(\mathrm{~s}, 4 \mathrm{H}, \mathrm{NCH}_{2}\right), 2.16$ and $2.02(\mathrm{~s}, 12 \mathrm{H}$, $\left.\mathrm{NMe}_{2}\right), 0.28\left(\mathrm{~s}, 9 \mathrm{H}, \mathrm{Me}_{3} \mathrm{Si}\right) .{ }^{13} \mathrm{C} \mathrm{NMR}\left(\mathrm{CDCl}_{3}, 50 \mathrm{MHz}\right): \delta$ 144.9, 142.5, 135.5, 133.3 (Ar), 62.7, $60.4\left(\mathrm{NCH}_{2}\right), 45.4,44.8$ $\left(\mathrm{NMe}_{2}\right), 4.0\left(\mathrm{Me}_{3} \mathrm{Si}\right)$.

Synthesis of $\left[\left(\mathrm{Me}_{3} \mathrm{Sn}\right)_{2}-\mathbf{1 , 4}-\left\{\mathrm{C}_{6}\left(\mathrm{CH}_{2} \mathrm{NMe}_{2}\right)_{4}-\mathbf{2 , 3 , 5 , 6}\right\}\right.$ (10). n-BuLi ( $3.3 \mathrm{~mL}, 1.5 \mathrm{M}$ solution in pentane, $5 \mathrm{mmol}$ ) was slowly added over a period of $5 \mathrm{~min}$ to a stirred solution of $\mathbf{2}(0.92 \mathrm{~g}$, $2 \mathrm{mmol})$ in THF $(15 \mathrm{~mL})$ at $-78^{\circ} \mathrm{C}$. The reaction mixture was allowed to warm to room temper ature over a period of 30 $\mathrm{min}$ and stirred for an additional $30 \mathrm{~min}$. Then a solution of $\mathrm{Me}_{3} \mathrm{SnCl}(1.0 \mathrm{~g}, 5 \mathrm{mmol})$ in THF $(10 \mathrm{~mL})$ was added in one portion, and the mixture was stirred for $2 \mathrm{~h}$. The resulting clear colorless solution was evaporated in vacuo to leave an off-white oily residue which was extracted with hot hexane (4 $\times 25 \mathrm{~mL}$ ). Concentration of the combined hexane extracts in vacuo afforded $10(0.67 \mathrm{~g}, 53 \%)$ as a white solid. Analytically pure col orless crystals of $\mathbf{1 0}\left(\mathrm{mp} 186-189^{\circ} \mathrm{C}\right)$, suitable for an X-ray analysis, were obtained by slowly cooling a saturated solution of $\mathbf{1 0}$ either in warm benzene or in hot hexane. ${ }^{1} \mathrm{H}$ NMR $\left(\mathrm{C}_{6} \mathrm{D}_{6}, 200 \mathrm{MHz}\right): \delta 3.52\left(\mathrm{~s}, 8 \mathrm{H}, \mathrm{NCH}_{2}\right), 1.98(\mathrm{~s}, 24 \mathrm{H}$, $\left.\mathrm{NMe}_{2}\right), 0.37\left(\mathrm{~s}, 18 \mathrm{H},{ }^{2} \mathrm{~J} \mathrm{SnH}=50 \mathrm{~Hz}, \mathrm{Me}_{3} \mathrm{Sn}\right) .{ }^{13} \mathrm{C} \mathrm{NMR}\left(\mathrm{C}_{6} \mathrm{D}_{6}\right.$, $50 \mathrm{MHz}$ ): $\delta 147.1$ ( $1 \mathrm{~J} \mathrm{snc}$ not observed, $\mathrm{C}_{\mathrm{ipso}}$ ), 142.5 (' $\mathrm{J} \mathrm{Snc}=49$ $\left.\mathrm{Hz}, 3_{\mathrm{Snc}}=27 \mathrm{~Hz}, \mathrm{C}_{\text {ortho }}\right), 60.6$ (3 $\left.\mathrm{J} \mathrm{snc}=26 \mathrm{~Hz}, \mathrm{CH}_{2}\right), 44.8$ $\left(\mathrm{NMe}_{2}\right),-1.9$ ( $^{1} \mathrm{~J} \mathrm{Snc}=371$ and $\left.355 \mathrm{~Hz}, \mathrm{Me}_{3} \mathrm{Sn}\right) .{ }^{119} \mathrm{Sn} \mathrm{NMR}$ $\left(\mathrm{C}_{6} \mathrm{D}_{6}, 75 \mathrm{MHz}\right): \delta-107.0\left(\mathrm{~s}, 5 \mathrm{f}\left(119_{\mathrm{Sn}}, 117_{\mathrm{Sn})}=75 \mathrm{~Hz}, \mathrm{SnMe}_{3}\right)\right.$. Anal. Calcd for $\mathrm{C}_{24} \mathrm{H}_{50} \mathrm{~N}_{4} \mathrm{Sn}_{2}: \mathrm{C}, 45.61 ; \mathrm{H}, 7.97 ; \mathrm{N}, 8.86$. Found: C, 45.65; H, 7.89; N, 8.81.

Reaction of $\left[\mathrm{Me}_{3} \mathrm{Sn}\left\{\mathrm{C}_{6} \mathrm{H}\left(\mathrm{CH}_{2} \mathrm{NMe}_{2}\right)_{4}-2,3,5,6\right\}\right]$ with nBuLi. To a stirred solution of $\mathrm{C}_{6} \mathrm{H}_{2}\left(\mathrm{CH}_{2} \mathrm{NMe}_{2}\right)_{4}-2,3,5,6(0.10$ $\mathrm{g}, 0.3 \mathrm{mmol})$ in hexane $(3 \mathrm{~mL})$ was added $\mathrm{n}$-BuLi $(0.2 \mathrm{~mL}, 1.6$ $M$ solution in hexanes, $0.32 \mathrm{mmol}$ ) in one portion. The reaction mixture was stirred for $17 \mathrm{~h}$ at room temperature, and all volatiles were evaporated in vacuo to afford a yellow oily residue. This residue was dissolved in THF ( $4 \mathrm{~mL})$, and to this solution at room temperature was added solid $\mathrm{Me} \mathrm{e}_{3} \mathrm{SnCl}$ (60 $\mathrm{mg}, 0.3 \mathrm{mmol}$ ) in one portion; the resultant reaction mixture was stirred for $15 \mathrm{~min}$ at room temperature. After this time, the volatiles were removed in vacuo and the resulting oily residue was extracted with hexane $(5 \mathrm{~mL})$. The hexane solution obtained from this procedure, which contains mostly the monostannane [ $\left.\mathrm{Me}_{3} \mathrm{Sn}\left\{\mathrm{C}_{6} \mathrm{H}\left(\mathrm{CH}_{2} \mathrm{NMe}_{2}\right)_{4}-2,3,5,6\right\}\right]$, was treated with n-BuLi $(0.2 \mathrm{~mL}, 1.6 \mathrm{M}$ solution in hexanes, $0.32 \mathrm{mmol}$ ) as described above and the mixture stirred for 17 $h$ at room temperature. To this solution was added $\mathrm{H}_{2} \mathrm{O}(3$ drops), and the reaction mixture was filtered through Celite. Evaporation of the filtrate in vacuo yielded a yellow oily residue, which was identified by ${ }^{1} \mathrm{H}$ NMR spectroscopy $\left(\mathrm{CDCl}_{3}\right.$ solution) as $\mathrm{C}_{6} \mathrm{H}_{2}\left(\mathrm{CH}_{2} \mathrm{NMe}_{2}\right)_{4}-1,2,4,5$.

Reactions of Silanes 5 and 9 and Stannanes 6 and 10 with $\mathbf{P d}(\mathrm{OAC})_{2}$ and $\left[\mathrm{M}^{\prime} \mathrm{Cl}_{\mathbf{2}}(\mathrm{COD})\right]\left(\mathbf{M}^{\prime}=\mathbf{P d}, \mathbf{P t}\right)$. Reactions were performed using typically $2 \mathrm{mmol}$ of silane or stannane and 2 (for 5 and 6) or $4 \mathrm{mmol}$ (for $\mathbf{9}$ and 10) of palladium(II) or platinum(II) substrate. Products were identified based on reported NMR data: $\left[\mathrm{M}^{\prime} \mathrm{Cl}\left\{\mathrm{C}_{6} \mathrm{H}_{3}\left(\mathrm{CH}_{2} \mathrm{NMe}_{2}\right)_{2}-2,6\right\}\right]\left(\mathrm{M}^{\prime}=\mathrm{Pd}\right.$ (11), $\left.{ }^{13} \mathrm{Pt}(\mathbf{1 2})^{13,17}\right),\left[\left(\mathrm{M}^{\prime} \mathrm{Cl}\right)_{2}-1,4-\left\{\mathrm{C}_{6}\left(\mathrm{CH}_{2} \mathrm{NMe}_{2}\right)_{4}-2,3,5,6\right\}\right]\left(\mathrm{M}^{\prime}=\right.$ $\mathrm{Pd}$ (15), $\mathrm{Pt}(\mathbf{1 6})),{ }^{8 b, c}\left[\mathrm{M}^{\prime} \mathrm{CIMe}(\mathrm{COD})\right]\left(\mathrm{M}^{\prime}=\mathrm{Pd}^{15}, \mathrm{Pt}^{18}\right)$, and $\left[\mathrm{Me}_{2} \mathrm{Sn}\left\{\mathrm{C}_{6} \mathrm{H}_{3}\left(\mathrm{CH}_{2} \mathrm{NMe}_{2}\right)_{2}-2,6\right\}\right]^{+} \mathrm{Cl}^{-}(\mathbf{1 4 a}) \cdot{ }^{16}$ (a) General Procedure for the Reactions of Silanes 5 and 9 and Stannanes 6 and 10 with $P d(O A c)_{2}$. A solution of the silane or stannane in $\mathrm{MeOH}(\sim 1 \mathrm{M})$ was added to a stirred solution of $\mathrm{Pd}(\mathrm{OAc})_{2}$ ( 1 molar equiv for $\mathbf{5}$ and $\mathbf{6}, 2$ molar equiv for 9 and 10) in $\mathrm{MeOH}(\sim 1 \mathrm{M})$ at room temperature, and the reaction mixture was stirred at this temperature until all $\mathrm{Pd}(\mathrm{OAC})_{2}$ had been converted. A solution of excess $\mathrm{LiCl}$ in $\mathrm{MeOH}(\sim 1 \mathrm{M})$ was then added at room temperature, and the reaction mixture was stirred for $15 \mathrm{~min}$ at this temperature. During this time a precipitate formed. The products in the $\mathrm{MeOH}$ solution and in the precipitate that had formed were analyzed by ${ }^{1} \mathrm{H}$ and ${ }^{13} \mathrm{C}$ NMR spectroscopy.

(b) General Procedure for the Reactions of Silanes 5 and 9 and Stannanes 6 and 10 with $\left[\mathrm{MCl}_{2}(\mathrm{COD})\right](\mathrm{M}=$ $\mathbf{P d}, \mathbf{P t})$. A solution of the silanes or stannanes in $\mathrm{CH}_{2} \mathrm{Cl}_{2}(\sim 1$ $\mathrm{M})$ was added to a stirred solution of $\left[\mathrm{MCl}_{2}(\mathrm{COD})\right](\mathrm{M}=\mathrm{Pd}$, Pt; 1 molar equiv for 5 and $\mathbf{6}, 2$ molar equiv for 9 and 10) in $\mathrm{CH}_{2} \mathrm{Cl}_{2}(\sim 1 \mathrm{M})$ at room temperature, and the reaction mixture was stirred at this temperature until all $\left[\mathrm{MCl}_{2}(\mathrm{COD})\right]$ had been converted. If during this time a white precipitate had formed, this precipitate was filtered off, washed with $\mathrm{CH}_{2} \mathrm{Cl}_{2}$, and dried in vacuo prior to analysis. The products in the $\mathrm{CH}_{2} \mathrm{Cl}_{2}$ solution and in the precipitate (if formed) were analyzed by NMR spectroscopy. The reaction of $\mathbf{1 0}$ with $\left[\mathrm{PtCl}_{2}(\mathrm{COD})\right]$ in $\mathrm{CH}_{2} \mathrm{Cl}_{2}$ afforded $\left[\left(\mathrm{Me}_{2} \mathrm{Sn}\right)_{2}-1,4-\left\{\mathrm{C}_{6}\left(\mathrm{CH}_{2} \mathrm{NMe}_{2}\right)_{4}-2,3,5,6\right\}\right]^{2+}\left(\mathrm{Cl}^{-}\right)_{2}(\mathbf{1 8 a})$ as a white solid. ${ }^{1} \mathrm{H} N M R\left(D_{2} \mathrm{O}, 200 \mathrm{MHz}\right): \delta 3.88(\mathrm{~s}, 8 \mathrm{H}$, $\left.\mathrm{NCH}_{2}\right), 2.50\left(\mathrm{~s}, 24 \mathrm{H}, \mathrm{NMe}_{2}\right), 0.81\left(\mathrm{~s}, 12 \mathrm{H},{ }^{2} \mathrm{JnH}=63 \mathrm{~Hz}\right.$, $\mathrm{Me}_{2} \mathrm{Sn}$ ). ${ }^{13} \mathrm{C}$ NMR $\left(\mathrm{D}_{2} \mathrm{O}, 50 \mathrm{MHz}\right): \delta 143.2$ (1) snc not observed, $\mathrm{C}_{\text {ipso }}$ ), 141.2 ( ${ }^{\mathrm{J}} \mathrm{SnC}=65 \mathrm{~Hz},{ }^{3} \mathrm{~J} \mathrm{snc}=40 \mathrm{~Hz}, \mathrm{C}_{\text {ortho }}$ ), 63.2 ( ${ }^{3} \mathrm{~J} \mathrm{snc}$ $\left.=35 \mathrm{~Hz}, 4 \mathrm{~J} \mathrm{snc}=11 \mathrm{~Hz}, \mathrm{NCH}_{2}\right), 48.1\left(\mathrm{NMe}_{2}\right),-4.3$ ( $1 \mathrm{~J} \mathrm{snc}=$ 453 and $434 \mathrm{~Hz}, \mathrm{SnMe}_{2}$ ). Evaporation of the filtrate yielded a pale yellow solid, identified as [PtCIMe(COD)].

Synthesis of $\left[\mathrm{Me}_{2} \mathrm{Sn}\left\{\mathrm{C}_{6} \mathrm{H}_{3}\left(\mathrm{CH}_{2} \mathrm{NMe}_{2}\right)_{2}-\mathbf{2 , 6}\right\}\right]^{+}\left(\left[\mathrm{Me}_{3}-\right.\right.$ $\left.\mathrm{SnCl}_{2}\right]^{-}$) (14b). A stirred solution of $\mathrm{Me}_{3} \mathrm{SnCl}(270 \mathrm{mg}, 1.35$ $\mathrm{mmol})$ and $6(228 \mathrm{mg}, 0.64 \mathrm{mmol})$ in $\mathrm{CH}_{2} \mathrm{Cl}_{2}(5 \mathrm{~mL})$ was heated at reflux temperature for $72 \mathrm{~h}$. Then the reaction mixture was evaporated in vacuo to $\sim 1 \mathrm{~mL}$, and hexane $(4 \mathrm{~mL})$ was added, which resulted in the precipitation of a white solid. This precipitate was filtered off, washed with hexane $(3 \times 5 \mathrm{~mL})$, and dried in vacuo. Yield: $350 \mathrm{mg}(95 \%)$ of a white solid, identified as 14b. Colorless crystals ( $\mathrm{mp} 154-157^{\circ} \mathrm{C}$ ) were obtained by layering a solution of $\mathbf{1 4 b}$ in $\mathrm{MeOH}$ with $\mathrm{Et}_{2} \mathrm{O}$. ${ }^{1} \mathrm{H} N M R\left(\mathrm{D}_{2} \mathrm{O}, 200 \mathrm{MHz}\right): \delta 7.41\left(\mathrm{t}, 1 \mathrm{H},{ }^{3} \mathrm{~J} \mathrm{HH}^{2}=7.5 \mathrm{~Hz}, \mathrm{ArH}\right)$, $7.23\left(\mathrm{~d}, 2 \mathrm{H}, 3 \mathrm{~J} \mathrm{HH}^{2} 7.5 \mathrm{~Hz}, \mathrm{ArH}\right), 3.82\left(\mathrm{~s}, 4 \mathrm{H}, \mathrm{NCH}_{2}\right), 2.44(\mathrm{~s}$, $\left.12 \mathrm{H}, \mathrm{NMe}_{2}\right), 0.82\left(\mathrm{~s}, 6 \mathrm{H},{ }^{2} \mathrm{~J} \mathrm{SnH}=64 \mathrm{~Hz}, \mathrm{Me}_{2} \mathrm{Sn}\right), 0.53(\mathrm{~s}, 9 \mathrm{H}$, $\left.{ }^{2} \mathrm{~J} \mathrm{SHH}=68 \mathrm{~Hz}, \mathrm{Me} S \mathrm{Sn}\right) .{ }^{13} \mathrm{C} \mathrm{NMR}\left(\mathrm{D}_{2} \mathrm{O}, 50 \mathrm{MHz}\right): \delta 145.3$ (3) $\mathrm{Snc}=36 \mathrm{~Hz}, \mathrm{Ar}$ ), 138.4 ( $1 \mathrm{~J} \mathrm{snc}$ not observed, $\mathrm{C}_{\mathrm{ipso}}$ ), 133.8 ( ${ }^{4} \mathrm{~J} \mathrm{SnC}$ $=11 \mathrm{~Hz}, \mathrm{Ar}), 128.5\left({ }^{2} \mathrm{~J} \mathrm{snc}=57 \mathrm{~Hz}, \mathrm{Ar}\right), 66.3\left({ }^{3} \mathrm{~J} \mathrm{snc}=34 \mathrm{~Hz}\right.$, $\left.\mathrm{CH}_{2}\right), 47.8\left(\mathrm{NMe}_{2}\right), 1.5$ ( ${ }^{1} \mathrm{~J} \mathrm{Snc}=499$ and $\left.478 \mathrm{~Hz}, \mathrm{Me}_{3} \mathrm{Sn}\right),-3.7$ ( $1 \mathrm{~J} \mathrm{SnC}=454$ and $434 \mathrm{~Hz}, \mathrm{Me}_{2} \mathrm{Sn}$ ). ${ }^{119} \mathrm{Sn} \mathrm{NMR}\left(\mathrm{CD}_{3} \mathrm{OD}, 74.85\right.$ $\mathrm{MHz}$ : $\delta 72.0$ (br s, cation), 34.1 (s, anion). Anal. Calcd for 14b corrected for $15 \mathrm{~mol} \%$ loss of $\mathrm{Me}_{3} \mathrm{SnCl}$ : C, 36.48; $\mathrm{H}, 6.05$; N, 5.14. Found: C, 36.50; H, 6.20; N, 5.09.

Synthesis of $\left[\left(\mathrm{Me}_{2} \mathrm{Sn}\right)_{2}-1,4-\left\{\mathrm{C}_{6}\left(\mathrm{CH}_{2} \mathrm{NMe}_{2}\right)_{4}-2,3,5,6\right\}\right]^{2+}$. $\left(\left[\mathrm{Me}_{3} \mathrm{SnCl}_{2}\right]^{-}\right)_{\mathbf{2}}$ (18b). A stirred solution of $\mathrm{Me} \mathrm{SnCl}_{3}(250 \mathrm{mg}$, $1.26 \mathrm{mmol})$ and 10 (196 $\mathrm{mg}, 0.31 \mathrm{mmol})$ in $\mathrm{CH}_{2} \mathrm{Cl}_{2}(10 \mathrm{~mL})$ was heated at reflux temperature $\left(\sim 40^{\circ} \mathrm{C}\right)$ for $72 \mathrm{~h}$, and this resulted in the formation of a white precipitate. This precipitate was filtered off, washed with $\mathrm{CH}_{2} \mathrm{Cl}_{2}(3 \times 5 \mathrm{~mL})$, and dried in vacuo. Yield: $195 \mathrm{mg}(59 \%)$ of $\mathbf{1 8 b}$ as a white solid, $\mathrm{mp}$ $>200^{\circ} \mathrm{C}$. Analytically pure colorless crystals, suitable for an $X$-ray analysis, were obtained by slow evaporation in air of a solution of 18b in a $1: 1$ mixture of $\mathrm{MeOH}$ and dibutyl ether. ${ }^{1} \mathrm{H}$ NMR $\left(\mathrm{D}_{2} \mathrm{O}, 200 \mathrm{MHz}\right): \delta 3.62\left(\mathrm{~s}, 8 \mathrm{H}, \mathrm{NCH}_{2}\right), 2.45(\mathrm{~s}, 24$ $\left.\mathrm{H}, \mathrm{NMe}_{2}\right), 0.76\left(\mathrm{~s}, 12 \mathrm{H}\right.$, ${ }^{2} \mathrm{JnH}=62$ and $\left.65 \mathrm{~Hz}, \mathrm{Me}_{2} \mathrm{Sn}\right), 0.52$ $\left(\mathrm{s}, 12 \mathrm{H},{ }^{2} \mathrm{~J} \mathrm{SnH}=66\right.$ and $\left.69 \mathrm{~Hz}, \mathrm{Me}_{3} \mathrm{Sn}\right) \cdot{ }^{13} \mathrm{C} \mathrm{NMR}\left(\mathrm{D}_{2} \mathrm{O}, 50\right.$ $\mathrm{MHz}): \delta 143.2$ ( ${ }^{1} \mathrm{~J} \mathrm{Snc}$ not observed, $\mathrm{C}_{\text {ipso }}$ ), 141.2 ( ${ }^{2} \mathrm{~J} \mathrm{Snc}=65$ $\left.\mathrm{Hz},{ }^{3} \mathrm{snc}=40 \mathrm{~Hz}, \mathrm{Ar}\right), 63.2\left({ }^{3} \mathrm{snc}=35 \mathrm{~Hz},{ }^{4} \mathrm{~J} \mathrm{snc}=11 \mathrm{~Hz}\right.$, $\left.\mathrm{CH}_{2}\right), 48.1\left(\mathrm{NMe}_{2}\right), 1.5$ ( ${ }^{1} \mathrm{~J} \mathrm{Snc}=501$ and $\left.479 \mathrm{~Hz}, \mathrm{Me}_{3} \mathrm{Sn}\right),-4.2$ ( $1 \mathrm{~J} \mathrm{SnC}_{\mathrm{Snc}} 453$ and $\left.433 \mathrm{~Hz}, \mathrm{Me}_{2} \mathrm{Sn}\right)$. ${ }^{119} \mathrm{SnNMR}\left(\mathrm{CD}_{3} \mathrm{OD}, 75\right.$

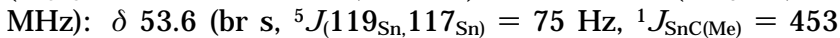
$\mathrm{Hz}$, J $\mathrm{SnC}(\mathrm{Ar})=730 \mathrm{~Hz}$, dication), $35.2\left(\mathrm{~s},{ }^{1} \mathrm{~J} \mathrm{SnC(Me)}=489 \mathrm{~Hz}\right.$, 
anion). Anal. Calcd for $\mathrm{C}_{28} \mathrm{H}_{62} \mathrm{Cl}_{4} \mathrm{~N}_{4} \mathrm{Sn}_{4}: \mathrm{C}, 31.39 ; \mathrm{H}, 5.83$; $\mathrm{N}, 5.23$. Found: $\mathrm{C}, 31.44 ; \mathrm{H}, 5.78 ; \mathrm{N}, 5.21 \%$.

X-ray Structure Determination of Complexes 9, 10, and 18b. Crystals suitable for X-ray diffraction were mounted on the tip of a glass fiber and were placed in the cold nitrogen stream on an Enraf-N onius CAD4-T diffractometer on rotating anode $(\mathrm{T}=150 \mathrm{~K}, \mathrm{MoK} \alpha$ radiation, graphite monochromator, $\lambda=0.71073$ ). Accurate unit cell parameters and an orientation matrix were determined by least-squares fitting of the setting angles of 25 well-centered reflections (SET4). ${ }^{28}$ The unit cell parameters were checked for the presence of higher lattice symmetry. ${ }^{29}$ Crystal data and details on data collection and refinement are collected in Table 4. Data were corrected for $L p$ effects and for the observed linear instability of the reference reflections. An empirical absorption correction was applied for complex $\mathbf{1 8 b}$ (DIFABS, ${ }^{30}$ as implemented in PLATON ${ }^{31}$ ); no absorption correction was applied for complexes 9 and $\mathbf{1 0 .}$

The structure of $\mathbf{9}$ was solved by automated direct methods (SHELXS86). ${ }^{32}$ The structures of complexes $\mathbf{1 0}$ and $\mathbf{1 8 b}$ were solved by automated Patterson methods and subsequent difference Fourier techniques (DIRDIF-92). ${ }^{33}$ The structures were refined on $\mathrm{F}^{2}$, using full-matrix least-squares techniques (SHE LXL-93 ${ }^{34}$ for complex 9 and SHELXL-9635 for complexes 10 and 18b); no observance criterion was applied during refinement.

For complex $\mathbf{1 0}$ hydrogen atom coordinates were refined;

(28) de Boer, J . L.; Duisenberg, A. J . M. Acta Crystallogr. 1984, A40, C410.

(29) Spek, A. L. J . Appl. Crystallogr. 1988, 21, 578.

(30) Walker, N.; Stuart, D. Acta Crystallogr. 1983, A39, 158.

(31) Spek, A. L. Acta Crystallogr. 1990, A46, C34.

(32) Sheldrick, G. M. SHELXS86 Program for crystal structure determination. University of Göttingen, Germany, 1986.

(33) Beurskens, P. T.; Admiraal, G.; Beurskens, G.; Bosman, W. P.; García-Granda, S.; Gould, R. O.; Smits, J. M. M.; Smykalla, C., The DIRDIF program system, Technical report of the Crystallography Laboratory, University of Nijmegen, The Netherlands, 1992. the starting positions were obtained from a difference F ourier synthesis. Hydrogen atoms of complexes $\mathbf{9}$ and $\mathbf{1 8 b}$ were included in the refinement on calculated positions, riding on their carrier atoms. The methyl hydrogen atoms were refined in a rigid group, allowing for rotation around the $\mathrm{N}-\mathrm{C}, \mathrm{Si}-\mathrm{C}$, or $\mathrm{Sn}-\mathrm{C}$ bonds; the methyl group containing $\mathrm{C}(12)$ of complex 9 was refined using an idealized disordered geometry.

The non-hydrogen atoms were refined with anisotropic thermal parameters. The hydrogen atoms were refined with a fixed isotropic thermal parameter related to the value of the equivalent isotropic displacement parameter of their carrier atoms by a constant factor.

Neutral atom scattering factors and anomalous dispersion corrections were taken from ref 36 . Geometrical calculations and illustrations were performed with PLATON; ${ }^{31}$ all calculations were performed on a DECstation 5000 cluster.

Acknowledgment. This work was supported in part (P.S., A.L.S., W.J .J .S., N.V.) by the Netherlands F oundation for Chemical Research (SON) with financial aid from the Netherlands Organization for Scientific Research (NWO).

Supporting Information Available: Further details of the structure determinations, including tables of atomic coordinates, bond lengths and angles, and thermal parameters for $\mathbf{9}, \mathbf{1 0}$, and $\mathbf{1 8 b}$ (12 pages). Ordering information is given on any current masthead page.

\section{OM $970492 X$}

(34) Sheldrick, G. M. SHELXL-93 Program for crystal structure refinement. University of Göttingen, Germany, 1993.

(35) Sheldrick, G. M. SHELXL-96 Program for crystal structure refinement. Beta test version. University of Göttingen, Germany, 1996

(36) Wilson, A. J . C., Ed. International Tables for Crystallography; Kluwer Academic Publishers: Dordrecht, The Netherlands, 1992; Vol. 